\title{
LEARNING From OUR MistaKes: THE AFTERMATH OF THE AMERICAN DIVORCE REVOLUTION AS A LESSON IN LAW TO THE REPUBLIC OF IRELAND
}

This process of learning from each other is at least as old as our nations, and its role in our development as nations has been incalculably beneficial. I would say that this process of learning from each other, far from being over, is as vital now as it has been at any point in the past. ${ }^{1}$

\section{INTRODUCTION}

On November 24, 1995, the people of the Republic of Ireland voted in favor of ending a fifty-eight-year-old constitutional ban on divorce. ${ }^{2}$ The vote to amend the nation's 1937 constitution in order to allow divorce was secured by the narrowest margin in any Irish referendum. ${ }^{3}$ Of the 1.6 million Irish citizens who voted on the referendum, $50.3 \%$ voted to allow divorce, while $49.7 \%$ voted against lifting the prohibition then in place. ${ }^{4}$ As a result of the vote, Ireland will amend its constitution near the end of 1996, and the Irish Parliament will enact a formal divorce bill alongside the amendment. $^{5}$

Ireland's new divorce laws "will be the most conservative in Europe." 6 The Fifteenth Amendment to the Irish Constitution will do more than simply remove the constitutional ban on divorce: it will provide "the actual ground rules for divorce in Ireland."7 Specifically, before granting a divorce, an

1. Mary Robinson, Constitutional Shifts in Europe and the United States: Learning from Each Other, 32 STAN. J. INT'L L. 1, 5 (1996). Mary Robinson is the President of the Republic of Ireland.

2. Christine M. Goldbeck, "For Better or for Worse" No More, AN SCATHAN (Dec. 1995) < http://www.underbridge.com/anscathan/issues/decemb $\sim 1 /$ divorce.htm $>$. Article 41.3.2 of the Irish Constitution states, "No law shall be enacted providing for the grant of a dissolution of marriage." IR. CONST. art. 41.3.2.

3. Golbeck, supra note 2 . The vote was so close that an unprecedented recount was ordered. The "Yes" vote in favor of dropping the divorce ban had won by 7520 votes. After the recount, the margin increased to 9163 votes. Coun Challenge to Vote for Divorce, NEwS OF IRELAND (visited Sept. 25, 1996) < http://www.iol.ie/resource/ip/noi/ nov2995/divorce. htm >.

4. Goldbeck, supra note 2.

5. Id. The presentation of the divorce referendum to the Irish electorate in November 1995 represented the first time in the history of the Republic that "a full draft [b]ill was published alongside the wording of a constitutional amendment." Maol M. Tynan, First Divorces Expected Late Next Year, THE IRISH TIMES, June 20, 1996, at 6.

6. Goldbeck, supra note 2.

7. Anna Margaret McDonough, When Irish Eyes Aren't Smiling-Legalizing Divorce in Ireland, 14 DiCK. J. INT'L L. 647, 656 (1996). 
Irish court will have to be satisfied that at the time proceedings are initiated the spouses have lived apart for at least four of the previous five years, and that there is no reasonable prospect of reconciliation. ${ }^{8}$ The Amendment also will require that proper provisions be made for the spouses and their children. ${ }^{9}$ Furthermore, the Amendment will permit additional conditions as set out by law. ${ }^{10}$ Such additional conditions will be set forth in the Family Law (Divorce) Bill, which will address "various aspects of divorce in Ireland." On June 27, 1996, the Bill passed its second stage in Ireland's House of Representatives (the "Dail"12) after a day of debates!" The following month the Bill passed through the Dail's committee stage, in which

8. Geraldine Kennedy, Spring Hopes for Substantial Majority in Poll, THE IRISH TiMES, Sept. 14, 1995, at 6. According to Ireland's Minister for Equality and Law Reform, Mervyn Taylor, there will be "no quickie divorce" under the Fifteenth Amendment, nor will there be a "divorce culture," as there has been in foreign jurisdictions where the waiting periods for divorce are much shorter. Id.

9. Id.

10. Id. The Fifteenth Amendment of the Constitution Act, 1995, provides as follows:

A court designated by law may grant a dissolution of marriage where, but only where, it is satisfied that-

i. at the date of the institution of the proceedings, the spouses have lived apart from one another for a period or periods amounting to, at least four years during the previous five

ii. there is no reasonable prospect of reconciliation between the spouses

iii. such provisions as the court considers proper having regard to the circumstances exist or will be made for the spouses, and children of both of them and any other person proscribed [sic] by law

iv. any further conditions proscribed [sic] by law are complied with.

McDonough, supra note 7, at $656 \mathrm{n} .60$ (quoting Fifteenth Amendment of the Constitution Act (1995) (Ir.)).

11. McDonough, supra note 7, at 656. The Bill, for example, will prescribe conditions on a court's jurisdiction in divorce proceedings. Kennedy, supra note 8, at 6 . In general, the Family Law (Divorce) Bill, 1995, consists of the following parts:

Part I. Planning and General

Part II. The Obtaining of a Decree of Divorce.

Part III. Preliminary and Ancillary Orders in or After the Proceedings for a divorce [sic]

Part IV. Income Tax, Capital Acquisition Tax, Capital Gains Tax, Probate Tax, and Stamp Duty

McDonough, supra note 7, at 656 n.61.

12. The Irish Parliament is called the "Oireachtas" and consists of two houses, the Senate (Seanad Eireann) and the House of Representatives (Dail Eireann). Ireland (visited Sept. 26, 1996) < http://www.odci.gov/cia/publications/95fact/ei.html > .

13. Divorce Bill Passes Second Stage, THE IRISH TIMES, June 28, 1996, at 11. 
it was amended. ${ }^{14}$ In October 1996, debate on the Bill was opened in Ireland's Senate (the "Seanad"), where it awaits passage. ${ }^{15}$ "The first [divorce] applications can be made three months after the Bill is signed into law," and the first divorce settlements are likely to be decreed by the end of 1997..$^{16}$

Although Ireland is just now making divorce available to its citizens, the ability to divorce one's spouse has existed in the United States since the colonial period. ${ }^{17}$ From before the Revolutionary War through the first half of the twentieth century, the grounds for obtaining a divorce in the various states were fairly limited, with all states requiring a showing of some form of marital offense on the part of one of the spouses. ${ }^{18}$ The typical statutes authorized divorce for adultery, desertion, and sometimes cruelty and other offenses. ${ }^{19}$ After World War II, however, in response to the nation's growing dissatisfaction with the existing "fault-based" divorce laws, courts in some states began to relax the statutory requirements for divorce. ${ }^{20} \mathrm{By}$ 1969, California had enacted a statute allowing divorce without a showing of marital fault. ${ }^{21}$ Other states soon followed its lead, sparking a widespread liberalization of divorce laws in the United States. ${ }^{22}$ Although American divorce laws are statutory and vary from state to state, most states today have adopted some type of "no-fault" divorce law, in which the "irretrievable breakdown" of a marriage or "irreconcilable differences" between spouses

14. Dermot Kelly, TDs Told VAT on Divorce Fees Cannot Be Waived, THE IRISH TIMES, July 18, 1996, at 2. Various amendments to the Divorce Bill were proposed and voted on during the committee stage in the Dail. One proposed amendment, for example, "sought to require spouses to show that they had attempted reconciliation and to produce a certificate to [that] effect before a court [would grant] a divorce decree." Dermot Kelly, 'Grey Area' Surrounds Marriages-Shatter, THE IRISH TIMES, July 17, 1996, at 5 [hereinafter Grey Area]. Because the Bill envisaged that counseling would be entered into on a voluntary basis, and because the amendment would add another layer of bureaucracy to divorce proceedings, the amendment was defeated by an eleven-to-nine vote. Id.

15. Counseling Urgently Needed in Cases of Marital Breakdown-Neville, THE IRISH Times, Oct. 11, 1996, at 6.

16. Tynan, supra note 5.

17. Homer H. Clark, JR., The Law of Domestic Relations in The United States $\S 11$, at 283 (1968).

18. Id.

19. Id.

20. Cynthia Starnes, Divorce and the Displaced Homemaker: A Discourse on Playing With Dolls, Partnership Buyouts and Dissociation Under No-Fault, 60 U. CHI. L. REV. 67, 77 (1993). After World War II, fault-based divorce laws increasingly were viewed as "annoying anachronisms" that frequently prevented divorce even when both spouses wanted one. Id.

21. Id.

22. Id. 
serves as either the sole or one of several grounds for dissolving a marriage. ${ }^{23}$

As divorce has become easier to obtain, divorce rates in the United States have skyrocketed, and a "divorce revolution" has ensued. ${ }^{24}$ Today, two people exchanging vows for the first time have only a fifty-fifty chance of staying married. ${ }^{25}$ If either of them has been married previously, the odds for divorce increase. ${ }^{26}$ Furthermore, although no-fault divorce laws were designed in part to encourage the equitable division of marital property upon divorce, ${ }^{27}$ such laws frequently have had adverse economic consequences for financially dependent spouses, most of whom are women. ${ }^{28}$ Where courts have taken a no-fault approach to asset distribution and spousal support payments, the results have been especially inequitable. First, although nofault laws seek to effect a "clean break" between spouses by encouraging a one-time division of marital property, in many cases an award of a portion (usually half) of the marital property often does not offset the future hardships associated with low income potential for women or other "displaced homemakers." 29 Second, no-fault laws are based on the theory that any maintenance, or alimony, awarded should be temporary and only for

23. Ira M. Ellman et al., Family Law: Cases, Text, Problems 177 (2d ed. 1991).

24. Thomas M. Mulroy, No-Fault Divorce: Are Women Losing the Battle?, 75-Nov. A.B.A. J. 76, 76 (1989). "Except for a brief period after World War II, the divorce rate in the United States increased only gradually from 1860 to the early 1960's." LENORE J. WEITZMAN, THE DIVORCE REVOLUTION xvii n.* (1985). Then, "[i]n the twelve years between 1963 and 1975 the divorce rate increased 100 percent, and in each successive year until 1981 the divorce rate surpassed all previous records for this country. The actual number of annual divorces climbed to a record high of 1.21 million in 1981." Id.

25. Mulroy, supra note 24 , at 76.

26. Id.

27. The elimination of both allegations of misconduct and "wrangling about guilt" from divorce proceedings was a principal aim of the no-fault laws. Such an aim "found expression not only in the substitution of the objective ground of breakdown for the former misconduct grounds, but also in . . . the elimination of guilt as a determinant in the decision about property settlement, alimony, and child custody." MAX RHEINSTEIN, MARRIAGE STABILITY, DIVORCE AND THE LAW 379 (1972).

28. Most of the dependent spouses in American marriages are women, because more women than men have stayed out of the labor force. The Bureau of Labor Statistics reported that in 1991, a total of 41.8 million women stayed out of the work force for various reasons. Approximately 22.7 million of them did not want jobs because they were "keeping house." Another 1.2 million wanted jobs but did not look for them due to home responsibilities. By contrast, only 415,000 men stayed out of the work force to "keep house," and only a "small number" did not look for work because of home responsibilities. Starnes, supra note 20, at 69 n. 3 (citing BUREAU of LABOR STATISTICS, UNITEd STATES DEPT. OF LABOR, 39 EMPLOYMENT AND EARNINGS No. 1, at 204, Table 35 (1992)).

29. Id. at 85. "A displaced homemaker is [usually] a woman whose principal job has been homemaking and who has lost her main source of income because of divorce, separation, widowhood, [etc.] . . . If she is employed at all, she works part-time or part of the year." Id. at 79 n. 46 . 
the purpose of enabling a disadvantaged spouse to obtain suitable employment. ${ }^{30}$ Such a theory of "rehabilitative" maintenance has proven to be overly optimistic about the opportunities available to dependent spouses, because it overlooks the reality of gender-based divisions of labor within the home and the costs of those divisions to dependent spouses who must enter the work force. ${ }^{31}$

These adverse consequences of American no-fault laws have not gone unnoticed in Ireland. In Ireland, divorce opponents and supporters alike have recognized the risks that attend liberal divorce policies like those in place in the United States and other Western nations. Aware of the economic consequences of "easy" divorce and seeking to avoid a "divorce revolution" in their own country, Irish lawmakers have adopted a rather conservative approach in formulating the nation's new divorce legislation. Although the form of divorce proposed in Ireland is not fault-based, it is relatively restrictive in its other conditions. ${ }^{32}$ By American standards, Ireland's imposition of a four-year-separation requirement seems especially limiting, "given that most states in the U.S. either prohibit judicial discretion to deny a divorce, or, in the case of a contested unilateral no-fault divorce, require a period of one year or less of separation." ${ }^{33}$ While Irish legislators understandably have tried to avoid some of the problems reported in the United States and other countries where divorce is readily available, the conservative approach these lawmakers have taken may prevent divorce from becoming a workable option for ending broken marriages in Ireland. If certain court reforms are not put into place by the end of 1996, when the proposed legislation is expected to become effective, couples could "experience delays of two to three years in obtaining divorce decrees following the commencement of divorce proceedings." 34

Ireland thus faces the challenge of striking a balance between making divorce a viable option for ending a marriage and enacting a divorce law that does not produce the economic inequities that are common in the United States and other liberal no-fault jurisdictions. As Ireland tackles this challenge, it should not hesitate to look to the United States as a model of both what to do and what not to do in the area of divorce law. Because

30. Id. at 85 .

31. Id. at $97,105$.

32. Michele Dillon, Debating DivorCe: Moral Conflict in IREland 1 (1993).

33. Id. By European standards, however, Ireland's four-year separation requirement appears less strict. "With the exception of Sweden and the Netherlands, which come closest to granting divorce on demand, other European societies take a much stricter view of marriage and its dissolution than does the United States. Id. at 1-2. For example, in the case of unilateral divorces, France requires a six-year separation. Additionally, France's dissolution statute has a "hardship" clause which permits a court to dismiss a divorce petition if divorce would cause excessive hardship to one or both of the parties. Id. at $176 \mathrm{n} .2$.

34. Tynan, supra note 5, at 6 (quoting Alan Shatter). 
support for divorce itself is far from overwhelming in Ireland, and because of a strong tide of conservatism running through Irish society, Irish lawmakers may rightly regard the American no-fault laws as being too liberal for their nation. Furthermore, conservative and liberal nations alike should seek to avoid the economic hardships that accompany the no-fault approach to property distribution and spousal support payments. Nevertheless, Ireland should remember that despite the many defects of American divorce law, such law has served as a workable option for ending broken marriages by not being too restrictive in its requirements.

This note considers both the recent referendum to legalize divorce in Ireland and the history and consequences of the divorce revolution in the United States. Part I begins by examining key legislation enacted by the Irish legislature between 1986 , when voters rejected divorce in a similar referendum, and 1995, when a narrow majority voted in favor of divorce. This section then considers the lack of unified support for divorce in Ireland, insofar as it reflects an underlying societal conflict between the desire to guarantee individual rights and the need to protect the common good. Part II draws a parallel between Ireland's difficulty in reconciling its Catholic values with the more secular views of the European Union and the sociopolitical tensions surrounding federalism in the United States. After a discussion of the sociopolitical conflicts that are common to both nations, the section suggests that the United States may serve as a useful model to Ireland, as the latter struggles both to find its place in the modern world and to adopt divorce laws compatible with its own social values. Next, Part III explores both the history and aftermath of the divorce revolution in the United States while focusing on the adverse consequences of the no-fault approach to property distribution and maintenance. The focus then shifts back to Ireland, as Part IV begins by pointing to Ireland's awareness of the economic consequences of liberal divorce laws. This section then suggests that in order to make divorce a real option for ending broken marriages, Ireland should preserve the opportunity to alter its divorce laws in the future by not writing them into the constitution. Furthermore, in order to protect the economic interests of women, Ireland should adopt legislation that allows a no-fault ground for divorce while permitting considerations of fault to affect property distribution and maintenance awards. Finally, Part V concludes with some concerns about both the possible ramifications of legalized divorce in Ireland and the existing social schism which the result of the referendum has highlighted. 


\section{The CONFLict BEHIND THE REFERENDUM: IndividuAL Rights V. THE COMMON GOOD}

\section{A. The Road to the Referendum: Changes in Irish Family Law from 1986 to 1995}

The first attempt to amend the Irish Constitution to allow divorce occurred in $1986,{ }^{35}$ when a legislative coalition, led by the Fine Gael political party, introduced a proposal to eliminate the prohibition on divorce contained in Article $41 .^{36}$ After the government announced that its proposal would be presented to the Irish electorate in a national referendum, a national opinion poll indicated that sixty-one percent of Irish voters intended to vote in favor of the amendment. ${ }^{37}$ As the referendum approached, however, later polls revealed that the level of support for the introduction of divorce was dropping. After nine weeks of intense campaigning by both pro- and anti-divorce factions, voters rejected the referendum by nearly two to one..$^{38}$ Although some supporters of the referendum blamed the reversal of public opinion on the Catholic hierarchy, which allegedly had used "scare tactics" to pressure citizens to vote against the referendum, ${ }^{39}$ others attributed

35. Although the government did not introduce a formal proposal to allow divorce until 1986 , prior to that time surveys had been conducted to measure the public's attitude toward the removal of the divorce ban. In 1971, when opinion polls first posed the question, $21 \%$ of those surveyed were in favor of removing the ban. The number in favor of divorce reached a "peak of 53 percent in 1983, with 77 percent expressing support for the introduction of divorce in certain circumstances." DiLloN, supra note 32, at 2.

36. Carol Coulter, Ten Year [sic] Wait is Finally Over for Those Who Campaigned for Divorce, THE IRISH TIMES, June 13, 1996, at 7. The amendment proposed in 1986 contained essentially the same provisions as those appearing in the Fifteenth Amendment of the Constitution Act, 1995. (See supra note 10 for text of the 1995 amendment.) However, the 1986 amendment required a five-year, rather than a four-year, separation period. DILLON, supra note 32 , at 1 .

37. DilloN, supra note 32, at 2.

38. Id.

39. McDonough, supra note 7, at 651-52. Although the hierarchy had issued a collective statement recognizing the right of Catholics to vote in good conscience in favor of divorce, several bishops individually offered their own guidance on how Catholics should vote. For example, Bishop Dominic Conway of the Elphin diocese warned people not to interpret the hierarchy's statement "too loosely." He cautioned that Catholics could not vote as they wished, but because they faced a "serious conscientious decision," they had to vote "in accordance with the law of God." DilloN, supra note 32, at 97 (quoting Bishop Conway). Such warnings and "scare tactics" by the clergy resurfaced prior to the 1995 referendum. One senior bishop claimed that divorcees were more likely to die from smoking or alcoholism and were more apt to commit suicide. John M. Brown, Ireland Readies for Battle on Divorce, FIN. TIMES, Sept. 2, 1995, at 2. Another bishop predicted that if the referendum passed, there would be a right-wing backlash "akin to the fanaticism of the Michigan Militia in the U.S." Id. 
the result to the amendment's silence on the issue of property distribution..$^{40}$ Whatever the reason for the referendum's defeat, the government soon began introducing legislation designed to reform existing marriage laws, the defects of which had been highlighted during the campaign. ${ }^{41}$ In the nine years between the defeat of the 1986 referendum and the approval of the 1995 referendum, the Irish parliament passed several key pieces of legislation addressing both property distribution and foreign divorce recognition. ${ }^{42}$ During the campaign before the 1995 referendum, divorce supporters, in their attempts to persuade citizens that Irish society was ready for change, often referred to the passage of such legislation. Even the President of Ireland, Mary Robinson, recognized the importance of those reforms: "What has happened since the issue (of divorce) was last before the people is a whole structure of reform of our marriage law, of various protections, of access to court remedies-a very thoughtful infrastructure has been developed. ${ }^{43}$

It is worth noting, however, that even before the legislature enacted such reforms, Ireland did provide some limited remedies for the problem of marital breakdown. For example, although the Irish Constitution prohibited divorce $a$ vinculo matrimonii, ${ }^{44}$ which effects a complete dissolution of the marriage contract, a court could issue a decree of a divorce a menso et thoro, ${ }^{45}$ which results in a separation of the parties by law. ${ }^{46}$ A court could grant such a decree only on three bases: cruelty, adultery, or unnatural practices. ${ }^{47}$ If one of the parties could establish any of these wrongdoings on the part of the other spouse, the court then had the power both to determine a husband's liability to pay alimony to his wife, and to declare the "guilty"

40. McDonough, supra note 7 , at 652 .

41. Coulter, supra note 36 , at 7 .

42. McDonough, supra note 7 , at 652 .

43. Department of Pol. Sci., Trinity College Dublin, The Irish Divorce Referendum 1995, at 2-3 (1995) <http://www.bess.tcd.ie/polsdept/divorce.htm> (quoting Mary Robinson).

44. A vinculo matrimonii is a Latin phrase meaning "[f]rom the bond of matrimony." BLACK'S LAW DICTIONARY 136 (6th ed. 1990).

45. A mensa et thoro is a Latin phrase commonly translated to mean "from bed and board." Id. at 81 .

46. Alan J. Shatter, ShatTer's Family LaW in the Republic of IRELAND 217 (3d ed. 1986). The remedy of divorce a mensa et thoro is misleadingly named "in that it does not amount to a divorce in the popular meaning of the term but only to a judicial separation of the spouses." Id. The courts' authority to grant a decree of divorce a mensa et thoro derives from two pieces of legislation. Under Section 13 of the Matrimonial Causes Act, 1870, the High Court inherited jurisdiction over such decrees from the Ecclesiastical Courts. The Courts Act, 1981, conferred a concurrent jurisdiction on the Circuit Court to determine these judicial separation proceedings. Id.

47. McDonough, supra note 7 , at 649 . 
spouse unfit to have custody of any children of the marriage. ${ }^{48}$ In addition to granting decrees of divorce $a$ mensa et thoro, the Irish courts recognized foreign divorces in certain circumstances. ${ }^{49}$ Before they would recognize a foreign divorce, Irish courts required both parties, at the time proceedings were initiated, to have been domiciled in the jurisdiction granting the divorce. $^{50}$ Such a requirement was sexist in its application, however, because the Irish common law considered a wife's domicile to be that of her husband. ${ }^{51}$ "[T]hus a husband could leave his wife in Ireland, move to England, and obtain a divorce which would be recognized as valid in Ireland. The husband would then be free to marry again."52 A wife, however, could not do the same, because her domicile would remain that of the husband she left behind in Ireland. ${ }^{53}$

Because the 1986 referendum highlighted these and other shortcomings of the courts' efforts to address marital breakdown, the Irish legislature sought to broaden and improve the remedies already existing. The legislature's first reform effort was to pass the Domicile and Recognition of Foreign Divorces Act of 1986, which replaced the common-domicile requirement with a policy requiring courts to recognize a foreign divorce if either spouse were domiciled in the foreign jurisdiction. ${ }^{54}$ The Act further abolished the common law rule that a wife's domicile depended upon her husband's. ${ }^{55}$ Although such measures would be expected to expand divorce recognition in Ireland, other provisions of the Act, along with the actual judicial implementation of the Act, prevented such broadened recognition from occurring. First, the Act itself limited the jurisdictions from which the courts had authority to recognize divorces. ${ }^{56}$ Second, "[t]he courts place[d] a heavy burden on [those] seeking foreign divorce recognition" by requiring that a party, in order to establish a new domicile, show an intention to abandon a previous domicile, along with an intent to live indefinitely in the

48. SHATTER, supra note 46 , at 227.

49. Article 41.3 .3 of the Irish Constitution addresses Irish recognition of foreign divorces:

No person whose marriage has been dissolved under the civil law of any other

State but is a subsisting valid marriage under the law for the time being in force within the jurisdiction of the Government and Parliament established by this Constitution shall be capable of contracting a valid marriage within that jurisdiction during the lifetime of the other party to the marriage so dissolved.

IR. CONST. art. 41.3.3.

50. SHATTER, supra note 46, at 255.

51. McDonough, supra note 7 , at 650 .

52. Id.

53. Id.

54. Id. at 652 .

55. Id.

56. Id. The Act allowed courts to recognize divorces obtained in England, Wales, Northern Ireland, the Isle of Man, and the Channel Islands. Id. at 652 n.35. 
foreign state. ${ }^{57}$ Irish courts did not recognize foreign divorces when there was a failure to meet the domicile requirement. ${ }^{58}$ Thus, because of the courts' "narrow interpretation of domicile," many people who relied on foreign divorces and subsequently remarried had their second marriages declared invalid in Ireland. ${ }^{59}$

After reforming the law with respect to the recognition of foreign divorces, the legislature adopted the substance of a bill proposed by Alan Shatter of the Fine Gael party. ${ }^{60}$ Designed to "streamline[ $]$ the proceedings for judicial separation," 1989 established six grounds for granting divorce a mensa et thoro. ${ }^{62}$ The Act provided for a no-fault basis for judicial separation, along with other grounds based on a marital offense. ${ }^{63}$ The legislation also allowed all other matters, such as maintenance and custody, to be determined at the same time a decree was granted. ${ }^{64}$

Although the Act provided a number of grounds for separation, the granting of a decree was not guaranteed upon application. The passage of the Act increased the number of applications for judicial separation without significantly affecting the acceptance rate; for example, couples filed 2718

57. Id. at 653 .

58. Id.

59. Id.

60. Coulter, supra note 36 , at 7.

61. Id.

62. McDonough, supra note 7, at 653. The Judicial Separation and Family Law Reform Act provides that:

An application for a decree of separation may be made if:

(1) the Respondent has committed adultery;

(2) the Respondent has behaved in such a way that the Applicant cannot reasonably be expected to live with Respondent;

(3) there has been desertion by the Respondent of the Applicant for a continuous period of at least one year immediately preceding the date of application;

(4) the spouses have lived apart for a continuous period of at least one year immediately preceding the date of application and that the Respondent consents to a decree being granted;

(5) the spouses have lived apart for a continuous period of at least three years preceding the date of application; or

(6) the marriage has broken down to the extent that the Court is satisfied in all circumstances that a normal marital relationship has not existed between the spouses for a period of at least one year immediately preceding the date of the application.

ld. at 653 n.44 (quoting JUdiCIAL SEPARATION AND FAMILY LAW REFORM ACT § 2(1) (1989)).

63. Coulter, supra note 36 , at 7 .

64. Id. 
petitions in 1992, but only 1015 were granted. ${ }^{65}$ Furthermore, even when a court did grant a decree, such decree did not dissolve the marriage, and the parties thus were prohibited from remarrying. ${ }^{66}$

Perhaps the most disturbing aspect of the Act, however, was the uninhibited discretion that it permitted the judiciary. The Act provided no clear standards for judges to use in determining whether an applicant had satisfied one of the six grounds for separation. ${ }^{67}$ For example, in the case of V.S. v. R.S., the court considered what constituted behavior with which one could not "reasonably be expected to live." ${ }^{68}$ The judge in that case found that although the defendant-husband had physically abused the plaintiff-wife, the plaintiff had failed to show that the defendant had behaved in such a way that she could not reasonably be expected to live with him. ${ }^{69}$ Nevertheless, the judge did grant a decree of judicial separation, on the ground that a normal marital relationship had not existed. ${ }^{70}$ The judge based this determination partly on the fact that the couple no longer had sexual relations. $^{71}$ Thus, a lack of sexual activity within a marriage justified separation, while physical abuse did not. ${ }^{72}$ With physical abuse not constituting a ground for separation, the usefulness of the Act seemed questionable. Because the Act gave vast discretion to judges, the results of individual cases were "inconsistent and at times appear[ed] entirely arbitrary." 73

The new laws addressing foreign divorces and judicial separation represented attempts by the legislature to expand the available remedies for marital breakdown. Although the new legislation failed to bring about significant improvements in Irish marriage law, it nonetheless opened the door for future reform. The changes in the law that occurred after 1986 formed the basis for the constitutional amendment that was approved in the 1995 referendum. ${ }^{74}$

\section{B. A Nation Divided}

Although there will no longer be an outright ban on divorce once the Fifteenth Amendment and the Divorce Bill become part of Ireland's laws, the

65. McDonough, supra note 7 , at 654.

66. Id. at 653-54.

67. Id. at 655 .

68. Id. (citing V.S. v. R.S., 199048 CA (Transcript) (Ir. H. Ct. 1990)).

69. Id.

70. $1 d$.

71. ld.

72. Id.

73. Id.

74. Coulter, supra note 36 , at 7. 
1995 referendum result in no way signifies the instant liberalization of a society long characterized by its conservatism and its strict adherence to the traditions of the Roman Catholic Church. ${ }^{75}$ Although the approval of the referendum undoubtedly represents a shift in public opinion since the referendum of 1986 , it is by no means evidence of a nation unified in its support for divorce. Indeed, the fact that the 1995 referendum passed by only a $0.6 \%$ majority suggests that Ireland is a nation "divided between those who wish to cling to [the] traditional Catholic Ireland, and those who wish to join the modern trend by focusing upon the rights of the individual."76 Furthermore, no bright line seems to separate the two groups. Even those who have advocated change have not urged radical reforms. For example, during the debate over the referendum, Bertie Ahern, the leader of the Fianna Fail political party, prophetically claimed that "a referendum allowing remarriage will only gain the necessary support if Irish people are

75. Ireland's Catholic identity is rooted in the nation's history. Catholicism arrived on the island with the British missionary, Patrick, in the fifth century. Dillon, supra note 32, at 11. Centuries later, in the face of the Protestant Reformation in Europe, Ireland remained loyal to Catholicism, while England became Protestant. Id. at 12. When England began colonizing Ireland in the sixteenth century, Ireland struggled to maintain an independent identity. Id. Throughout the next four centuries of colonial domination, the Irish "appropriated Catholicism as a symbolic force against British Protestant oppression." Id. at 14. Ireland's Catholic tradition continued even after the nation achieved independence in 1922, and today Catholicism still "acts as a central cohesive force for the Irish, providing them with a sense of community and unity." Id. at 14,20. Today $93 \%$ of Irish citizens are Catholic. Ireland, supra note 12.

76. McDonough, supra note 7 , at 672 . The referendum's narrow victory led Des Hanafin, an anti-divorce leader and former senator, to bring a court case challenging the referendum result on the grounds that the government wrongly spent public funds in its efforts to secure a "Yes" vote. Hanafin Can Appeal to Supreme Court, THE IRISH TIMES, Mar. 2, 1996 , at 4 . When, prior to the referendum, the government had allocated $£ 500,000$ for an "information" campaign which advocated a "Yes" vote, Patricia McKenna challenged the expenditure and won. A week before the vote, the Supreme Court of Ireland held that the expenditure of public funds in seeking a particular result to a referendum was unconstitutional, and it ordered the government to cancel the remainder of its advertising campaign. When the vote was returned in favor of divorce, however, Hanafin claimed that the unconstitutional expenditure had interfered with the conduct of the referendum, contrary to the Referendum Act of 1924, and had influenced the outcome. After the High Court found against him on both counts, Hanafin appealed to the Supreme Court. Although the Supreme Court found that the government's expenditure did indeed interfere with the referendum, the Court concluded that Hanafin had failed to prove that such interference had materially affected the outcome of the vote. Coulter, supra note 36 , at 7 .

Hanafin and McKenna have not been the only ones to challenge the way in which the referendum was conducted. In October 1996, The Irish Times reported that Fionnuala Sherwin, a worker on the "No" campaign during the referendum, had brought an action against the government challenging the constitutionality of the monitoring of votes in referenda. Unlike Hanafin's suit, though, Sherwin's suit has not challenged the outcome of the referendum. Vote Monitoring Challenged, THE IRISH TIMES, Oct. 15, 1996, at 4. 
satisfied about the safeguards [that the amendment would provide]." $77 \mathrm{He}$ also stated the position of his party that " $[t]$ he right to remarriage should never be an easy option." Progressive Democrats, warned that the proposed amendment would directly conflict with provisions of the Irish Constitution guaranteeing protection for the family. ${ }^{79}$ During the Divorce Bill's committee stage in the Dail, Eamon O'Cuiv of Fianna Fail suggested that the referendum proposal put before the people in November 1995 had envisaged "divorce as a last resort." $80 \mathrm{He}$ further expressed his concern that the Bill which was taking shape was dismantling that proposal. ${ }^{81}$ Even the executive branch took a cautious stance: Prime Minister John Bruton urged lawmakers to reflect on why so many citizens voted against the referendum. ${ }^{82}$

Because a conservative approach is being taken in the formulation of the new divorce law, it is far from certain that divorce will become a workable option for ending a broken marriage in Ireland. Despite the vein of conservatism running through the discourse on divorce, Irish legislators nevertheless seem to appreciate the suffering endured by the 75,000 individuals who are trapped in broken marriages in Ireland: ${ }^{\mathbf{B 3}}$ According to the Minister for Equality and Law Reform, Mervyn Taylor, the Divorce Bill is meant to address the welfare of those citizens whose lives have been devastated by marital breakdown, but who have remained married in "the insistent eye of the law." ${ }^{84}$ Similarly, Alan Shatter of the Fine Gael party has expressed hope that the Bill will offer the promise of a better future to the thousands of people whose marriages had in reality ended years ago. ${ }^{85}$ Furthermore, legislators see the right to divorce and remarry as a solution to the growing problem of illegitimacy which has resulted from the government's refusal to recognize relationships formed after the breakdown of a marriage. More than one-fifth of Irish children are now born out of

77. Mary Cummins, Ahern Calls for Separation Period of at Least Five Years Before Divorce, THE IRISH TIMES, May 15, 1995, at 4 (quoting Bertie Ahern).

78. Id. (quoting Bertie Ahern).

79. Dermot Kelly \& Michael O'Regan, O'Malley Warns Proposed Amendment Could Be Contested and Lead to Situation of No Divorce, THE IRISH TIMES, Sept. 29, 1995, at 6. Article 41.1 .1 of the Irish Constitution provides: "The State recognises the Family as the natural primary and fundamental unit group of Society, and as a moral institution possessing inalienable and imprescriptible rights, antecedent and superior to all positive law." IR. CONST. art. 41.1.1. Article 41.1.2 states: "The State, therefore, guarantees to protect the Family in its constitution and authority, as the necessary basis of social order and as indispensable to the welfare of the Nation and the State." IR. CONST. art. 41.1.2.

80. Grey Area, supra note 14, at 5.

81. Id.

82. McDonough, supra note 7, at 672 .

83. Kennedy, supra note 8, at 6.

84. Divorce Bill Passes Second Stage, supra note 13, at 11 (quoting Mervyn Taylor).

85. Tynan, supra note 5 , at 6 . 
wedlock. ${ }^{86}$ Because many lawmakers believe that the illegitimacy of the new family negatively impacts both the parents and the children of subsequent unions, the real thrust of Fifteenth Amendment is arguably to legalize remarriage. ${ }^{87}$

Accompanying the legislators' sensitivity to the reality of marital breakdown in Ireland, ${ }^{88}$ is an awareness of the need for the State to provide support systems, along with legislation, to ensure that divorce will actually be available to those couples whose suffering the State seeks to alleviate. Dr. Michael Woods, Fianna Fail's spokesman on equality and law reform, has indicated that his party will insist on the establishment of an "action programme that must go hand in hand with the Bill" to provide counseling and mediation services and to ensure the expansion of the Family Court system. ${ }^{89}$ Alan Shatter also has warned that, in conjunction with the Divorce Bill's enactment, significant reform of the court structure will be required to enable the system to cope with the anticipated demand for divorce, so that divorces can be obtained within a reasonable period. ${ }^{90}$ Currently, courts take eighteen months just to decide separation cases. ${ }^{91}$ According to Shatter, if the needed court reforms are not put into place, "couples may experience delays of two to three years in obtaining divorce decrees following the commencement of divorce proceedings." 92 Helen Keogh, spokeswoman on equality and law reform for the Progressive Democrats, has acknowledged that once divorce is formally introduced in Ireland, "[the legislature] must ensure that the reality of marriage breakdown is dealt with in a caring, professional and effective manner." 93

86. Brown, supra note 39 , at 2.

87. Id.

88. According to Mervyn Taylor, "No right to remarry has not meant no [marital] breakdown" in Ireland. Kennedy, supra note 8, at 6 (quoting Mervyn Taylor). At the time of the referendum, "there was approximately one application for judicial separation for every six marriages." Id. Furthermore, the incidence of marriage itself has decreased. In 1986, there were 18,573 marriages. Divorce Bill Passes Second Stage, supra note 13, at 11. By 1994 , the number had decreased to 16,297 , with 2806 applications for judicial separation in the same period. Brown, supra note 39, at 2.

89. Tynan, supra note 5, at 6 (quoting Dr. Michael Woods).

90. Id.

91. Id.

92. Id. (quoting Alan Shatter). The delay of two to three years would be in addition to the four years of separation required before divorce proceedings can even be initiated. Thus, from the time that marital breakdown occurs, a couple may have to wait up to seven years to get a divorce.

93. Id. (quoting Helen Keogh). 


\section{The New Discourse on Rights}

Ireland faces the challenge of striking a balance between making divorce a viable option for ending a marriage and establishing a divorce law that does not depart too radically from the conservative referendum supported by a narrow majority of voters. ${ }^{94}$ As conservatives struggle to protect the family as the "fundamental unit group of Society," 95 and modernists fight for changes in the law for the welfare of individuals trapped in bad marriages, the effects of these competing values on Irish society remain to be seen. ${ }^{96}$ What is clear, however, is that the challenge that Ireland faces with regard to the divorce issue stems from a basic societal conflict that is not unique to Ireland alone. Every democratic society faces the challenge of protecting individual rights and, at the same time, safeguarding the common good. ${ }^{97}$ In Ireland, supporters of divorce have argued that individuals who have endured miserable marriages ought to be given a chance to make a fresh start. ${ }^{98}$ Those opposed to divorce have focused on the negative consequences that divorce can have on both families and society as a whole. ${ }^{99}$ The two viewpoints "represent an inherent societal conflict: to what extent may one retain individual freedoms without creating a non-functioning individualistic society?"100

Traditionally, the Catholic Church in Ireland has taught not only that divorce is morally wrong, ${ }^{101}$ but also that a society which exalts individual

94. The Divorce Bill introduced in the Dail in June 1996 was almost identical to the legislation announced before the referendum in November 1995. Changes to the Bill from the legislation published before the referendum were of a technical nature. Those changes related to pension adjustment orders, the pursuit of spouses who fail to honor maintenance orders, and certain provisions of the Family Law Act. Id. It remains to be seen what additional changes to the law will occur after the Bill passes through the Seanad.

95. IR. CONST. art. 41.1.1.

96. Some citizens view the results of the referendum as "Ireland's wake-up call to join the rest of the modern world." McDonough, supra note 7, at 647. Yet for others, joining the modern world "means sharing in its misfortunes." Id. To Irish conservatives, becoming a modern nation will cost "far more than they believe Irish society ought to pay." Id. at 648 .

97. The Preamble to the Irish Constitution sets out the dual goals of promoting the common welfare and ensuring individual rights. The language employed suggests that individual rights are made possible through the protection of the common good. For instance, the Preamble states that in adopting the Constitution, the "people of Éire [Ireland]" sought "to promote the common good . . . so that the dignity and freedom of the individual may be assured." IR. CONST. preamble.

98. McDonough, supra note 7, at 661-62.

99. Id. at 662.

100. Id.

101. The Catholic Church maintains that marriage is "permanent and indissoluble." Id. at 650-51. In 1985, the Irish hierarchy issued a definitive pastoral letter on marriage and the family, entitled Love Is for Life. DiLLON, supra note 32, at 95 . That letter in part stated, "the compassion of Jesus cannot be invoked as a reason for departing from his teaching on divorce 
rights at the expense of the common good will suffer. ${ }^{102}$ Members of the Irish hierarchy have warned that the "cult of excessive individualism," which puts the individual man or woman at the center of things, interferes with the establishment of a community in the "true sense." 103 Largely because of the influence of the Catholic Church, the Irish people lack even the basic vocabulary that would allow a discourse on individual rights. ${ }^{104}$ Thus, unlike in the United States "where it is commonplace for people to freely use a language that talks about their individual rights, the use of a 'rights' discourse in Irish society is uncommon." 105 The passage of the divorce referendum, however, has ushered in some discussion of individual rights. For example, in urging Catholics to adopt a more compassionate view of divorce, the Reverend John Marsden of the Church of Ireland Theological College declared that "all the Christian churches still have much to learn from liberalism's regard for the human individual."106 According to Marsden, the individual rights tradition serves as "an important counterweight to too great a reliance on arguments based on conceptions of the common good." 107 Claiming that concern for the human individual should be a central tenet of Christian ethics, Marsden has criticized the Catholic bishops' pre-referendum statement praising abandoned spouses who had given "an authentic witness of fidelity" by not entering a new relationship. ${ }^{108}$ To Marsden, asking people to stay in bad marriages places additional burdens on those who are already victims. ${ }^{109}$

\section{The United States as a Natural Model}

Accompanying the recent discussion of individual rights in Ireland has been the recognition that the country in fact no longer stands alone in rugged isolation from the rest of the world. ${ }^{110}$ Since becoming a member of the

. . . The bond uniting married couples is a sacramental bond, coming from God alone

.. . no human authority, no State or civil court can put this bond asunder." Id. at 98.

102. McDonough, supra note 7, at 666.

103. Id. (quoting Christine Newman, Cult of Excessive Individualism Leads to False Idea of Freedom, THE IRISH TIMES, Oct. 3, 1995, at 4 (referring to Bishop Lee's homily on the then upcoming referendum)).

104. DilloN, supra note 32, at 15.

105. Id.

106. Andy Pollak, Compassionate View of Divorce Urged, THE IRISH TIMES, Sept. 4, 1996 (quoting the Reverend John Marsden).

107. Id. (quoting the Reverend John Marsden).

108. Id. (quoting the Catholic bishops' pre-referendum statement).

109. Id.

110. Historically, the Irish people have valued and protected their isolation from the rest of the modern world. After winning independence from Britain in 1922, Ireland embarked on a "project of establishing a truly sovereign country that was independent not just politically but economically and culturally." DILLON, supra note 32 , at 21 . Thus, while other Western 
European Economic Community (now the European Union) in 1973, ${ }^{11}$ Ireland has become increasingly connected to the rest of the Western world. As Ireland has established its place in the European family, it has reexperienced, this time in a global context, the familiar conflict between individual rights and the common good. In the context of the European Union, the conflict involves the rights of the member states to retain their sovereignty versus the need for international laws and standards designed for the good of the Union. In becoming part of the Union, the member states must necessarily surrender certain national rights. In 1963, the European Court of Justice ${ }^{12}$ declared the European Union to be "a new legal order of international law for the benefit of which the States have limited their sovereign rights. ${ }^{113}$ Like many other member nations, Ireland has been hesitant to surrender certain of its national interests for the sake of European integration. ${ }^{114}$ Thus, concerned about the extent to which European law could intrude on Irish social values, Ireland recently negotiated a special protocol to protect its constitutional provision protecting the right to life of the unborn. ${ }^{115}$ Similarly, Denmark secured protection for its law prohibiting nationals of other member states from acquiring second homes in its territory, and Britain obtained the right to "opt out" of a timetable for the

nations "were becoming more interconnected and interdependent, insular self-sufficiency became the dominant objective in Ireland." Id. at 22 . However, when the Irish government began to change its economic policy in the late 1950's to focus on industrial development, Ireland could no longer remain a lonely agrarian island. Rapid industrial growth "marked this period as the watershed in Ireland's modernization" and began to erode the country's tradition of cultural protectionism. Id. at 25 .

111. Id. at 26.

112. As one of four governmental branches of the European Union, the European Court of Justice "adjudicates Community law both among the governmental branches of the Community and between the Community and its Member States." Paul W. Butler \& David L. Gregory, A Not So Distant Mirror: Federalism and the Role of Natural Law in the United States, the Republic of Ireland, and the European Community, 25 VAND. J. TRANSNAT'L L. 429,439 (1992).

113. Robinson, supra note 1 , at 8 (emphasis added).

114. In asserting the supremacy of European law, the European Court of Justice has "frequently operated against the grain of the [member] nations which-not unnaturally-have sought to limit the implications of the voluntary delimitation of their own sovereign power." Id.

115. Id. at 9. Fearing that Irish courts might overturn Section 42 of the Offenses Against the Person Act of 1861, which criminalized abortion in Ireland, pro-life groups successfully fought for a constitutional referendum to protect the rights of the unborn. In 1982, the Eighth Amendment Bill to the Irish Constitution passed by a two-to-one margin. Butler \& Gregory, supra note 112, at 458. Codified as Article 40.3.3 of the Irish Constitution, the Amendment states, "The State acknowledges the right to life of the unborn and, with due regard to the equal right to life of the mother, guarantees in its laws to respect, and, as far as practicable, by its laws to defend and vindicate that right." IR. CONST. art. 40.3.3. 
move to a single European currency. ${ }^{116}$ As Ireland's President Mary Robinson ${ }^{117}$ has noted, "[t]here is a perception . . . held by a substantial number of European opinion formers-that the European ideal threatens local interests, local culture, local heritage, and local values."118

Just as Ireland is not alone in confronting the internal challenge of balancing individual rights and the common welfare within its democratic society, it is not alone in facing its global challenge of protecting its own sovereign needs while contributing to the needs of the greater European Union. In many respects, there is a parallel between Ireland's difficulty in reconciling its Catholic values with the more secular views of the European Union, and the political and social tensions surrounding the concept of federalism in the United States. ${ }^{119}$ The courts of the United States, the Republic of Ireland, and the European Union all have grappled with issues involving "[p]rivacy, personal individual dignity, and the most intimate and fundamental human rights." 120 The United States, despite the conflicts that constantly arise within its federal system of government, nevertheless has existed as a union of self-governing, yet interdependent, states for more than 200 years. Because the United States has survived, and indeed flourished, as such a union, the Irish people may rightly look to America's social and political history for guidance, as their nation struggles to define its own place within the European Union and the Western world in general. Recognizing the United States as a natural role model for her country, Ireland's President Robinson observed that at the time the United States was founded, "the very notion of such a Union was as daring and as far-fetched as some would say the notion of a European Union is today." 121 In constructing its own social policies, Ireland in the past has looked to the example provided by the United States. According to President Robinson, "[i]t was to the pioneering creativity of the Warren Court of the late 1950's and early 1960's that [Ireland's] own Supreme Court in Dublin looked when it began in the mid 1960's to fashion [Ireland's] 1937 Constitution into the modern rights-based document that it is today." 122 As Ireland faces the global challenge of federalism within the European Union and the internal challenge of balancing

116. Robinson, supra note 1 , at 9 .

117. Mary Robinson became the first woman President of Ireland on December 3, 1990. In her inaugural speech, President Robinson announced, "the stage is set for a new common European home based on respect for human rights, pluralism, tolerance, and openness to new ideas." Id. at 1 (quoting the inaugural speech of President Mary Robinson).

118. Id. at 10 .

119. Butler \& Gregory, supra note 112 , at 429 . The "tensions between the sovereign prerogative of the Republic of Ireland and the role of federalism in the European Community are broadly analogous to themes of federalism in the United States." Id. at 430.

120. Id. at 430.

121. Robinson, supra note 1 , at 6 .

122. Id. at 5. 
individual rights and the common good, it should continue to look to the United States for guidance. Furthermore, the United States may serve as an especially useful model to Ireland as the latter tackles the challenges surrounding its new divorce laws. Because divorce, in one form or another, has been available in America since the colonial period, ${ }^{123}$ the United States has more than two centuries of experience in an area of law that Ireland is just now adopting.

\section{THE HISTORY AND AFTERMATH OF THE AMERICAN DIVORCE REVOLUTION}

\section{A. From Fault to No-Fault: A Brief History of American Divorce Law}

From its beginning, American law allowed divorce more freely than did British law due to a strong Protestant tradition in the colonies. ${ }^{124}$ In colonial New England, ${ }^{125}$ statutes authorized divorce for adultery, desertion, and sometimes cruelty and other offenses. ${ }^{126}$ After the Revolutionary War and through the nineteenth century, the divorce laws of the various states were characterized by great diversity and were subject to frequent change. ${ }^{127}$ Nevertheless, through the first half of the twentieth century, all states required that all divorce cases be brought within one or another category of marital offense, ${ }^{128}$ the broadest (and hence often the most useful) of these

123. CLARK, supra note 17 , at 283.

124. In England, ecclesiastical courts had exclusive jurisdiction over cases of marital breakdown until 1857, when jurisdiction was transferred to the civil court system and divorces were authorized in cases of adultery. Id. at 282. Until that time, the Church of England, through the ecclesiastical courts, had refused to grant divorce for any reason, although it did permit judicial separation, without a right of remarriage, on the grounds of cruelty and adultery. Id. at 281. The Matrimonial Causes Act of 1937 added desertion, cruelty, and some other offenses as grounds for divorce. Id. at 282 . Today divorce is available on no-fault grounds in England, but the time requirements for obtaining a divorce on such grounds are quite restrictive. A mutual consent divorce is available only after a two-year separation, and a unilateral divorce is available only after a five-year separation. DiLloN, supra note 32, at 176 n.2.

125. While the courts and legislatures in New England occasionally granted divorces during colonial times, the South generally followed the English tradition during this period. Absolute divorces were unknown, and judicial separations were rare. ELLMAN ET AL., supra note 23 , at 162 .

126. ClaRK, supra note 17, at 283.

127. Id.

128. The offense necessary to support a divorce decree depended on the statutory language of the particular state. All states acknowledged adultery as a ground for divorce, and, until 1937, it was the only ground for divorce in New York. Desertion was also recognized almost universally as a sufficient ground. In order to establish desertion, plaintiffs in most states had to prove that the defendant had abandoned all marital duties, and that for a minimum period of time, often prescribed by statute, the parties had not lived together. 
categories being "cruelty" 129 or "indignities"130 or some equivalent. ${ }^{131}$

After World War II, a new spirit of individualism sparked questions about the legitimacy of these "fault-based" divorce laws, which were increasingly viewed as anachronistic and inconvenient. ${ }^{132}$ After the 1950's, the virtues of the family were no longer so openly celebrated. ${ }^{133}$ A new cultural emphasis on individual fulfillment was reflected in the emerging women's movement, the increasing number of women entering the work force, and the declining birth rate. ${ }^{134}$ The new focus on self, rather than family, generated increased dissatisfaction with the fault-based divorce laws, which were viewed as imposing constraints on individual freedom. The dissatisfaction with fault-based divorce laws led many people to try to circumvent the restrictions those laws imposed. For example, because "[t]he national law of divorce was a hodgepodge," with some states having relatively strict divorce laws and others having more liberal ones, the practice of "migratory divorce" developed. ${ }^{135}$ In order to avoid the strict divorce laws of one jurisdiction, people with money and the desire to travel would relocate to another state that had liberal divorce laws and a short residency requirement. ${ }^{136}$ Moreover, even in states that had "stringent law[s] strutting proudly on the books," the enforcement of those laws was often lax. ${ }^{137}$ Indeed, by the middle of the twentieth century, divorce law in the United States had become one of the most unsettled and heterogeneous areas of law in the nation:

Cruelty was a third common ground allowed under the divorce laws of most states. While many states required the plaintiff to show bodily harm as a result of the defendant's actions, some states allowed proof of mental suffering as well. ELLMAN ET AL., supra note 23, at 16566.

129. Especially in states that had relatively restrictive grounds for divorce, "the official divorce law of the books bore no relation to the law in practice." Id. at 167. In jurisdictions that allowed "cruelty" as a ground for divorce, the law was particularly subject to expansion in individual cases. Id. at 167. As noted by Professor Homer Clark in the 1968 edition of his text, "In many states, especially in the West, a divorce for cruelty may be had for the asking, providing it is uncontested. . . . It is the means by which divorce has become easy in most of the United States without the necessity for enlarging the statutory grounds." CLARK, supra note 17 , at 341 .

130. Wyoming, for example, allowed divorce on the ground of "indignities" that made the marriage "intolerable." ELLMAN ET AL., supra note 23, at 165.

131. CLARK, supra note 17, at 283.

132. Starnes, supra note 20 , at 77.

133. Id. at 76.

134. Id. at 77 .

135. ELLMAN ET AL., supra note 23, at 165.

136. Id. Before the 1870's, Indiana was one state that attracted the "tourist trade" for divorces. However, after moralists in that state campaigned vigorously for stricter divorce laws, the legislature enacted a new statute that effectively "shut the divorce mill down." Id.

137. Id. 
Divorce law stood as an egregious example of a branch of law tortured by contradictions in public opinion, trapped between contending forces of perhaps roughly equal size; trapped, too, in a federal system with freedom of movement back and forth, and beyond the power and grasp of any single state . . . . ${ }^{138}$

In response to the growing dissatisfaction with the existing divorce laws, courts in strict jurisdictions began to relax the statutory requirements for divorce and, in some cases, to allow fabricated stories of adultery and other marital wrongs to pass as evidence of fault. ${ }^{139}$ Such judicial intervention eventually prompted legislatures to take action. By 1969, California had enacted a statute allowing divorce without a showing of marital fault. ${ }^{140}$ California's new law permitted divorce upon one party's assertion that "irreconcilable differences have caused the irremediable breakdown of the marriage." 141 One year later, the National Conference of Commissioners on Uniform State Laws approved the Uniform Marriage and Divorce Act (UMDA), which allowed divorce in the case of an "irretrievably broken" marriage without the requirement of fault. ${ }^{142}$ Other states soon followed California's lead and adopted statutes similar to the UMDA. ${ }^{143}$ The new "no-fault" laws, which are still in place today, ${ }^{144}$

138. Id.

139. Starnes, supra note 20 , at 77 . In states with more restrictive divorce grounds, the number of fabrications was perhaps greater. The need to prove specific behavior demonstrating one spouse's faults often led to "an unpleasant and embarrassing public exposure of the parties' marital difficulties." ELLMAN ET AL., supra note 23, at 168. Furthermore, "where the spouses were agreed upon divorce, but had not in fact engaged in conduct recognized as grounds under their state's divorce law, there was temptation to invent the necessary offenses." Id. While "[c]ollusion and connivance were recognized grounds for denying a divorce," they were rarely invoked. Id.

140. Starnes, supra note 20 , at 77 . California's statute was "the first law in the Western world to abolish completely any requirement of fault as the basis for marital dissolution." WEITZMAN, supra note 24 , at 15 .

141. Weitzman, supra note 24, at 15 (quoting CAL. CIV. Code $\S 4508$ (West 1983)). In enacting the new statute, California's legislature meant to "eliminate the adversarial nature of divorce and thereby to reduce the hostility, acrimony, and trauma characteristic of faultoriented divorce." ld.

142. Starnes, supra note 20 , at 77.

143. Id.

144. A 1987 survey indicated that 15 states have "pure no-fault laws" in which marital breakdown is the only ground for divorce, all fault-based grounds having been abolished. ELLMAN ET AL., supra note 23, at 177 (citing Herma H. Kay, Equality and Difference: $A$ Perspective on No-Fault Divorce and its Aftermath, 56 U. CIN. L. REV. 1, 5-6 (1987)). Among these states are Arizona, California, Colorado, Florida, Hawaii, Iowa, Kentucky, Michigan, Minnesota, Montana, Nebraska, Oregon, Washington, Wisconsin, and Wyoming. Id. Twenty-one other states have achieved the same result by merely adding a modern no-fault ground, such as "breakdown," to traditional fault-based grounds, in effect allowing parties to 
evolved from a partnership theory of marriage. Under this theory, a marriage is a partnership of individuals "who may dissolve their relationship at will, compel the liquidation and distribution of their property, and upon winding up their affairs, leave the relationship with no further obligations to one another. ${ }^{n 145}$

Not surprisingly, as divorce became easier to obtain, divorce rates in the United States skyrocketed and a "divorce revolution" ensued. ${ }^{146}$ The divorce rate rose sharply throughout the 1970's and then reached a plateau in the early 1980's, when it achieved a level where one in two recent marriages could be expected to end in divorce. ${ }^{147}$ In 1981, the actual number of annual divorces reached a record high of 1.21 million. ${ }^{148}$ Today, there are still more than one million divorces each year in the United States. ${ }^{149}$ While the increased divorce rate and the no-fault reforms occurred at roughly the same time, it is not clear that the enactment of no-fault divorce laws was itself responsible for the increased incidence of divorce in the United States. As advocates of no-fault divorce correctly have noted, the passage of the nofault laws was the outgrowth of American society's changing views of

choose between a fault or no-fault divorce. Id. Among these 21 states, Ohio is unique in that it has "both a divorce law based on fault and a procedure for dissolution of marriage based on an agreement of the spouses without any statutory specification of a breakdown standard." Herma H. Kay, Equality and Difference: A Perspective on No-Fault Divorce and its Aftermath, 56 U. CIN. L. REV. 1, 6 (1987). The 14 remaining states and the District of Columbia are also considered no-fault jurisdictions, because they include, among their faultbased grounds, an incompatibility or separation standard that effectively permits parties to obtain a divorce without proving fault. ELLMAN ET AL., supra note 23, at 177.

145. Starnes, supra note 20 , at 78 . The partnership theory of marriage, also referred to as the "marital-sharing" theory, has been stated and characterized in various ways. LAWRENCE W. WAGgoner ET AL., FAMILY PROPERTY LAW 465 (1991). Under one view, the theory is portrayed as "an expression of the presumed intent of husbands and wives to pool their fortunes on an equal basis, share and share alike." Id. (quoting MARY ANN GLENDON, THE TRANSFORMATION OF FAMILY LAW 131 (1989)). Such an approach regards the economic rights of each spouse as "deriving from an unspoken or imputed marital bargain under which the partners agree that each is to enjoy a half interest in the fruits of the marriage." Id. Under another view, the theory is cast in restitutionary terms and embraces a "return-of-contribution" notion. Under this approach, the law entitles each spouse to compensation for non-monetary contributions to the marriage, as "a recognition of the activity of one spouse in the home and to compensate not only for this activity but for opportunities lost." Id. (quoting GLENDON, supra note 145, at 131 ). However it is conceived, the partnership theory of marriage has had important implications with respect to the distribution of marital property under the no-fault system of divorce. See infra text accompanying notes 169-90.

146. Mulroy, supra note 24 , at 76.

147. Judith S. Wallerstein \& Sandra Blakeslee, Second Chances: MEN, WOMEN, AND CHILDREN A DECADE AFTER DIVORCE 303 (1990).

148. WEITZMAN, supra note 24 , at xvii $n$.*.

149. Id. at xvii. 
marriage and divorce. ${ }^{150}$ It seems likely that a number of different social factors combined to contribute to the divorce "boom."151 Nevertheless, there is evidence to indicate that, at least in some states, the adoption of no-fault divorce was a significant factor contributing to the increase in divorce rates. ${ }^{152}$ For example, one study which examined thirty-five states adopting new no-fault laws before 1980 found that twenty-five of them experienced higher than average increases in divorce rates when the new laws went into effect. ${ }^{153}$ In eleven of those states, the increase in the divorce rate was more than twice the previous rate of increase. ${ }^{154}$ The study's researcher concluded that "[n]o-fault laws, operationalized as a single variable, had a significant impact on divorce rates, with the major thrust delayed for a year."155

\section{B. The Aftermath of the Divorce Revolution: Economic Hardship for Dependent Spouses}

While the increased divorce rates were perhaps not surprising given the greater facility of divorce following the no-fault reforms, less expected were the economic inequities that the new laws would engender in many instances. ${ }^{156}$ Although no-fault divorce laws were designed partly to encourage the equitable treatment of men and women upon divorce, such laws frequently have had adverse economic consequences for women. ${ }^{157}$ For example, Lenore Weitzman's ten-year study of the California no-fault system found that women and the minor children in their households experienced a seventy-three percent decline in their standard of living within the first year following a divorce. ${ }^{158} \mathrm{Men}$, on the other hand, experienced a forty-two percent rise in their standard of living within the same time period..$^{159}$

150. Mulroy, supra note 24 , at 76 . In the 1960's and early 1970's there was marked departure from traditional notions of marriage. "The feminist movement had a significant impact on traditional thinking as women sought the sexual freedom which they perceived men enjoyed. Pressure built to liberalize divorce laws and make them more equitable." Id.

151. Lynn D. Wardle, No-Fault Divorce and the Divorce Conundrum, 1991 B.Y.U. L. REV. 79, 119 (1991).

152. Id.

153. Id. at 117.

154. Id. at 117-18.

155. Id. at 118 (quoting Marvel, Divorce Rates and the Fault Requirement, 23 L. \& SOC'Y REV. 543, 563 (1989)).

156. Starnes, supra note 20 , at 78.

157. Mulroy, supra note 24 , at 77.

158. WEITZMAN, supra note 24 , at 36.

159. Id. The significant discrepancy in living standard between former husbands and wives is partly due to the fact that men are not typically ordered to pay alimony and are responsible only for what are often meager child support payments. Because men do not have to share their incomes with their former wives and children after divorce, they are left with more money to spend on themselves. On the other hand, women typically earn much less 
Ironically, such inequities have resulted from the avowed purpose of the nofault laws to treat the sexes equally at the time of divorce. In reality, the nofault laws have treated men and women "as if they were equal . . . at the point of divorce." 160 In so doing, the laws have ignored the structural inequality between men and women in the larger society. ${ }^{161}$ Spurred to action by demands for fair and efficient divorce laws, state legislatures adopted no-fault laws without accounting for the unfortunate reality that within American society most women are not on equal economic footing with men. ${ }^{162}$ In fact, "[d]ivorced women and divorced men do not have the same opportunities: the women are more likely to face job and salary discrimination and [are] more likely to be restricted by custodial responsibilities." 163 Furthermore, in treating men and women "equally" at the time of divorce, no-fault laws also have ignored the economic inequalities that marriage itself produces. ${ }^{164}$ Traditionally, marriage has economically disadvantaged women rather than men. ${ }^{165}$ Most married women have given priority to their families, while most married men have given priority to their careers. ${ }^{166}$ Even when both husband and wife are in the work force, it is more likely that the woman will forego further education and training, while the man acquires additional education and work experience. ${ }^{167}$ Because a woman's earning capacity is often impaired during marriage, while a man's is often enhanced, "marriage itself can be partly responsible for the dramatically different prospects that men and women face after divorce." 168 Such a discrepancy in the financial prospects of men and women frequently results when courts apply no-fault principles in distributing marital property and awarding maintenance.

money and often have custody of their children, whom they must support with little financial assistance from their ex-husbands. Id.

160. Id. at 35.

161. Id.

162. Mulroy, supra note 24 , at 77 . Studies confirm that women earn less than their male counterparts in the workplace. Wages of white women have been reported to be $63 \%$ of white men's wages. Starnes, supra note 20, at 139 n.25 (citing NATIONAL COMM. ON PAY EQUITY, PAY Equity: AN Issue of RaCe, EThnicity, AND SeX 1 (1987)). Presumably the percentages are even lower for women of color.

163. WEITZMAN, supra note 24 , at 35.

164. Id. at xi.

165. Id. at 36 .

166. Id. at xii.

167. Id.

168. Id. at 36 . 


\section{The "Clean Break" Theory of Property Distribution}

Because they are designed to effectuate a "clean break"169 upon divorce, no-fault laws promote a final settlement of the parties' mutual obligations through a one-time division of marital property. ${ }^{170}$ However, the presumption that such a division equitably settles the parties' rights and responsibilities "has proved to be wishful thinking." ${ }^{171}$ The typically insubstantial amount of tangible marital property, together with the broad discretion which judges have in dividing that property, often make the distribution of property "both insignificant and unpredictable." 172 First, when a minimal amount of tangible assets are available at the time of divorce, which is often the case, ${ }^{173}$ an award of a portion (usually half ${ }^{174}$ ) of the marital property will not offset the future hardships of parties with low income potential, such as women or "displaced homemakers." 175 For example, when a couple's only important asset is equity in a marital residence, such equity can only be divided upon sale of the home. ${ }^{176}$ Since courts often do order a sale of the marital home, a displaced homemaker, or

169. The notion of a "clean break" at divorce derives from the partnership model of marriage embraced by no-fault theory. "At the core of this partnership model are two simple concepts: divorce should be available at will; and divorce should terminate the parties' mutual responsibilities, thus affording each party an emotional and financial clean break." Starnes, supra note 20 , at 108 .

170. Id. at 85 .

171. Id.

172. Id.

173. Research has revealed that "the average divorcing couple has relatively few assets, and those assets are typically of relatively low value." WEITZMAN, supra note 24 , at 55 . For example, a 1977 random sampling of Los Angeles divorce decrees revealed that less than half of divorcing couples had any major assets, such as a house, business, or pension. Id.

174. Only nine states require an equal (fifty-fifty) division of marital assets between the two spouses: Arizona, Arkansas, California, Idaho, Louisiana, Nevada, North Carolina, New Mexico, and Wisconsin. Most states have equitable distribution standards by which courts have the discretion to divide assets "as justice requires." There is usually more variation in awards under equitable distribution standards, since such laws give judges considerable latitude. (However, many equitable jurisdiction states follow the common law tradition of awarding one-third of the property to the wife and two-thirds to the husband.) Because of widespread dissatisfaction with the uncertainty of awards occasioned by equitable distribution, equal division rules are likely to become more common in the future. Already there is a tendency for judges in some equitable distribution states, such as Hawaii, to begin with the presumption that a fifty-fifty division is "equitable." In such states, the burden of proof shifts to the judge to justify an unequal award. Id. at $47-48$.

175. Starnes, supra note 20 , at 85 . For a definition of a "displaced homemaker," see supra note 29 . The phenomenon of the displaced homemaker is far from rare in the United States. The Census Bureau counted 15,600,000 displaced homemakers in 1989, an increase of $12 \%$ over the figures for 1980 . Most middle-aged and younger homemakers were displaced by divorce or separation. Id. at 79.

176. Id. at 86. 
otherwise disadvantaged spouse, "may thus leave the marriage with limited income potential, few if any assets, and no home." 177 Second, because trial judges have virtually unfettered discretion in dividing assets, the financial fate of the economically disadvantaged party often depends on the goodwill or prejudice of a particular judge. ${ }^{178}$ Most states have adopted equitable distribution statutes, ${ }^{179}$ which give trial courts the discretion to divide property in a just or reasonable manner, with the only constraint often being that a judge "consider" certain factors. ${ }^{180}$ Given such broad discretion, judges may base their decisions on any of the statutory factors which they personally deem important. ${ }^{181}$ Furthermore, they may give a single factor, such as one spouse's greater financial contribution to the marriage, "disproportionate and dispositive weight." 182 Recent studies have suggested that the significant latitude given to trial judges in divorce cases has been subject to abuse. At least thirty states have established task forces to investigate the extent of gender bias in their courts. ${ }^{183}$ Of the nine states that have reported their findings, each one concluded that "gender bias

177. Id. at 86-87. Concerned by the possibility of such hardships in cases involving limited assets, some courts have attempted to expand the definition of marital property in order to increase the assets available for distribution. For example, a court might include within the pool of marital property such nontraditional assets as pensions, goodwill in a business, and professional degrees or licenses. Id. at 87 . However, while most states now regard pensions and retirement benefits as marital assets, only a few consider a professional degree, goodwill, insurance benefits, and other career assets to be marital property. WEITZMAN, supra note 24, at 47 . In one case, a court refused to classify a husband's business degree as a marital asset on the ground that such a degree "is simply an intellectual achievement," which has "none of the attributes of property in the usual sense of that term." Starnes, supro note 20 , at 89 (quoting In re Marriage of Graham, 574 P.2d 75, 76 (Colo. 1978)). Moreover, even those courts which do treat professional degrees as marital property afford no help to the more typical homemaker whose spouse has not earned such a degree. Starnes, supra note 20 , at 91.

178. Starnes, supra note 20 , at 92.

179. See supra note 174.

180. Starnes, supra note 20 , at 92 . Under UMDA $\$ 307$, judges are directed to consider the following factors in deciding how to divide marital property:

the duration of the marriage, and prior marriage of either party[;] antenuptial agreement of the parties[;] the age, health, station, occupation, amount and source of income, vocational skills, employability, estate, liabilities, and needs of each of the parties[;] custodial provisions[;] whether the apportionment is in lieu of or in addition to maintenance[;] and the opportunity of each for future acquisition of capital assets and income.

Id. at 139 n. 111 (quoting UMDA § 307, 9A ULA 238 (West 1987) (Alternative A)). While UMDA $\$ 307$ lists certain factors that judges should consider in distributing marital property, it does not expressly prohibit a judge from considering any other factor, except marital misconduct. Furthermore, $\S 307$ does not specify the weight to be given to each factor. Id.

181. Id. at 93.

182. Id.

183. Id. 
detrimental to women permeates every aspect of marital dissolution and child support." 184

Even when substantial marital assets are available and judicial bias is absent, no-fault laws still have the potential to produce inequities, because they reduce the bargaining power of women and dependent spouses in certain situations. Before the no-fault reforms, the "status of women in divorce was a mixed blessing." 185 If women had no titled interest in property acquired during marriage, they stood to receive nothing at the time of divorce. ${ }^{186}$ A woman who wanted a divorce and who was not financially independent often had to choose between losing all her assets in a divorce or

184. Id. (quoting Lynn H. Schafran, Gender and Justice: Florida and the Nation, 42 FLA. L. REV. 181, 187 (1990)). A study in Michigan found that the "resolution of economic issues is often premised on misconceptions about the economic consequences of divorce for women," and that "[s]ome judges and attorneys fail to recognize a spouse's loss of career or career potential as a meaningful contribution to the economic partnership of the marriage." Id. at 93-94 (quoting MiCHIGAN SUP. CT. TASK FORCE ON GENDER ISSUES IN THE COURTS, CONCLUSIONS AND RECOMMENDATIONS 8 (1990)).

185. Mulroy, supra note 24 , at 76.

186. Id. Today, the majority of states have "separate-property"systems of ownership for marital property. In a separate-property system, the husband and wife are separate owners of the assets that each acquires after marriage (except for property that they have agreed to hold jointly). By contrast, nine states (Arizona, California, Idaho, Louisiana, Nevada, New Mexico, Texas, Washington, and Wisconsin) have "community-property" systems, under which husband and wife own all assets acquired by either of them during marriage in equal, undivided shares. WAGGONER ET AL., supra note 145, at 466-67. Prior to the no-fault reforms, in the separate-property states, "title" to the property controlled upon divorce, and courts had no jurisdiction over property that was held in the name of one spouse. For example, if the marital home was titled in the name of the husband, it belonged to him alone and could not be divided by a court at the time of divorce. WEITZMAN, supra note 24 , at 46 47. After no-fault laws were enacted, however, most of the separate-property states adopted "equitable distribution upon divorce statutes," which approximate the rules in communityproperty systems by implementing a partnership theory of marriage. WAGGONER ET AL., supra note 145, at 471-72. Under these statutes, courts have broad discretion to "assign to either spouse property acquired during the marriage, irrespective of title, taking into account the circumstances of the particular case and recognizing the value of the contributions of a nonworking spouse . . . to the acquisition of that property." Id. (quoting J. GREGORY, THE LAW OF EQUITABLE DISTRIBUTION $\S 1.03$, at 1-6 (1989)).

A key difference between equitable-distribution and community-property regimes, however, is that equitable-distribution statutes allow for a considerable degree of judicial discretion in the distribution of property (See supra text accompanying notes 178-84), while community-property regimes automatically grant each spouse a one-half interest in the earnings of the other immediately upon acquisition. Id. Furthermore, among equitabledistribution states, there are considerable differences in the statutes concerning what property is subject to distribution. Id. at $\mathbf{4 7 2}$. In 15 states, a court may consider all property owned by either spouse as potentially available for distribution upon divorce. In another 27 states, a court may divide only that property acquired during the marriage. WEITZMAN, supra note 24 , at $46-47$. 
staying in an unhappy marriage. ${ }^{187}$ However, because it required the consent of both spouses or a showing of fault, a divorce was not easily obtained. ${ }^{188}$ Thus, in cases where the husband wanted a divorce, women had a distinct advantage: "If a man wanted his freedom, he would have to pay for it. Where the law failed to give women explicit property rights, it allowed them to extract economic security through bargaining. A divorce decree was often an expensive commodity." ${ }^{189}$ Thus, while the no-fault principle of equitable distribution has given women certain assets to which they had no previous claim, it has taken away from them the power to refuse consent to a divorce until their demands for economic security are met. ${ }^{190}$

\section{The Theory of Rehabilitative Maintenance}

No-fault laws are based on the theory that any award of maintenance, or "alimony" in the language of the prior fault-based laws, ${ }^{191}$ should be temporary and for the purpose of rehabilitating a disadvantaged spouse. ${ }^{192}$ First, in accordance with no-fault's goal of making dependent spouses selfsufficient after divorce, "there has been a shift from permanent awards based on the premise of the wife's continued dependency, to time-limited transitional awards." 193 In theory, transitional awards are to continue long enough for the recipient to attain the education or training needed for suitable employment; ${ }^{194}$ i.e., maintenance should last for the period of time needed to "rehabilitate" the dependent spouse. ${ }^{195}$ In practice, however, courts have

187. Mulroy, supra note 24 , at 77.

188. Id.

189. Id.

190. Id. at 80 .

191. In distinguishing between "alimony" under the prior fault-based law, and "maintenance" under no-fault law, a Colorado court explained in a 1983 decision that "maintenance, unlike its predecessor, alimony, is primarily concerned with insuring that, after dissolution, the basic [economic] needs of a disadvantaged spouse are met." WEITZMAN, supra note 24, at 45 (quoting In re Marriage of Mirise, 673 P.2d 803 (Colo. Ct. App. 1983)). Such a distinction has proved to be significant, as states increasingly have redefined al imony as maintenance and have made awards dependent upon the recipient's earning potential and economic need. Id.

192. Starnes, supra note 20 , at 85 .

193. WEITZMAN, supra note 24, at 32. Between 1968 and 1972, permanent maintenance (i.e., maintenance continuing until death or remarriage) dropped from $62 \%$ to $32 \%$ of all maintenance awarded in Los Angeles County. By 1972, two-thirds of the maintenance awards were transitional awards for a limited duration. The median duration of these transitional awards was 25 months. Id. at 32-33.

194. Id. at 45-46.

195. Arguably, the term "rehabilitative maintenance" has pejorative connotations when applied to the case of a displaced homemaker, since it "suggests that the homemaker has not been engaged in productive or socially useful work during marriage." Id. at 46 . 
limited maintenance awards to a few years at most. ${ }^{196}$ Second, since the nofault reforms, a new "economic" focus has driven the courts' decisions regarding spousal support payments. ${ }^{197}$ Focusing less on the standard of living during marriage, courts have paid more attention to each spouse's earning capacity and to the dependent spouse's ability to become selfsupporting. ${ }^{198}$ While courts still consider factors such as the recipient's age and the length of the marriage, they have placed greater importance on strictly economic criteria, such as a dependent spouse's occupation and predivorce income. ${ }^{199}$ However, in applying the new criteria, courts have denied maintenance both to spouses with low pre-divorce incomes and to spouses with "limited and marginal employment histories," apparently on the belief that such spouses are capable of supporting themselves. ${ }^{200}$

The result of the "economic" approach to maintenance has been that the "vast majority of divorced women, roughly five out of six divorced, are not awarded [maintenance]." 201 According to the Census Bureau, during the last 100 years, the percentage of divorced women awarded maintenance actually has decreased from sixteen percent to fifteen percent. ${ }^{202}$ Furthermore, the average maintenance award in 1989 was approximately $\$ 4000$ per year, and "one-fourth of those women awarded [maintenance were] unable to collect because of non-compliance and poor enforcement."203 Perhaps in response to such outcomes, some courts have relaxed the standards they apply in determining maintenance awards. Many states have come to realize that permanent support may be necessary in some cases. ${ }^{204}$ New York has a statute that shifts a court's attention from a "needs" analysis back to a focus on the marital standard of living. ${ }^{205}$ In recent years, some appellate courts have overturned trial courts awarding only meager payments to older wives who could not easily become self-supporting. ${ }^{206}$ Nevertheless,

196. Id. Several states now have fixed time limits on all maintenance awards. New Hampshire limits awards to three years (provided there are no minor children), Delaware to two years, and Kansas to one year. Although New Hampshire and Kansas do allow the time periods to be extended in certain cases, the burden of proof falls on the recipient to show that an extension is necessary. Id.

197. Id. at 45.

198. Id.

199. Id. at 33.

200. Id. In Otis v. Otis, the court upheld an award of only four years of support payments to a 45-year-old homemaker of 24 years, even though she had not worked since the birth of the parties' child 23 years earlier. 299 N.W.2d 114, 117 (Minn. 1980), cited in Starnes, supra note 20 , at 103.

201. WEITZMAN, supra note 24, at 33.

202. Mulroy, supra note 24 , at 80 .

203. Id.

204. Id.

205. Id.

206. WeITZMAN, supra note 24 , at 46. 
"[i]f there is a trend developing for the benefit of women, it is not yet statistically significant." 207 Because the no-fault laws have grown out of the presumption that dependent spouses will become self-sufficient after divorce, ${ }^{208}$ the majority of disadvantaged spouses are either being denied maintenance altogether, or are awarded small amounts for short periods of time to "ease the transition" to independence. ${ }^{209}$

\section{Confronting THE Challenge: StRIKING A Balance Between NO-FAULT AND FAULT IN THE REPUBLIC OF IRELAND}

\section{A. A Recognition of the Risks}

As courts in the United States have continued to divide marital property and to award support payments in accordance with "equitable" principles, and as American homemakers have continued to suffer losses, the citizens of Ireland have taken note. In Ireland, divorce opponents and supporters alike have recognized the risks which attend liberal divorce policies like those in place in the United States and other Western nations. In the campaigns leading up to the 1995 referendum, those opposed to divorce argued that the availability of divorce would both increase the rate of marital breakdown and impoverish women and children. ${ }^{210}$ Divorce opponents pointed to studies conducted in other countries for results showing a surge of divorces when they first became available there and a steady increase in divorce rates thereafter. ${ }^{211}$ Even outsiders warned of the downside to divorce. For example, Leo Cash, an English family lawyer, advised the Irish people to look at the situation in England before voting to legalize divorce. ${ }^{212}$ He warned that in his country the living standard of a divorcing couple plummets, forcing England to spend 180 million pounds each year on legal aid services. ${ }^{213}$

There was a similar awareness of the adverse consequences of divorce before the referendum in 1986. Prior to that referendum, the Anti-Divorce Campaign ("ADC") emphasized economic issues in its campaign for a "No" vote, with the impoverishment of women as one of the central themes of its

207. Mulroy, supra note 24 , at 80 .

208. The theory of rehabilitative maintenance has proven to be overly optimistic about the possibilities for "rehabilitation" of the dependent spouse, because it overlooks the reality of gender-based divisions of labor within the home and the costs of those divisions to dependent spouses who must enter the work force. Starnes, supra note 20, at 97, 105.

209. WEITZMAN, supra note 24 , at 33.

210. McDonough, supra note 7, at 665-66.

211. Id. at 665 .

212. Id. at 664 .

213. Id. at 664-65. 
discourse. ${ }^{214}$ For example, the ADC's Bernadette Bonar argued that, unlike in Ireland where there are welfare benefits designated specifically for deserted women, in other countries where divorce is available, filing for divorce is the only way in which deserted women can hope to get financial support. ${ }^{215}$ To this observation, Bonar added a warning: "But don't forget that men just don't pay maintenance to their wives. [Sixty percent] of [divorced women] in England go straight onto social welfare. And in America, $85 \%$ of men, even after a court order, refuse to pay maintenance to their wives." 16 William Binchy, a law professor and the ADC's primary spokesman, argued that the introduction of divorce would result in hardships both for older women, who had sacrificed careers by raising families, and for younger women, who had children at home. ${ }^{217}$ According to Binchy, "[t]hese two categories, studies throughout the world have shown again and again, are the categories that have been hit hardest by the introduction of divorce based on failure of a marriage." 218

On the other side of the debates in both 1986 and 1995, proponents of divorce also recognized the economic hardships that divorce had wrought in other countries. Nevertheless, they maintained that divorce was necessary to end the suffering which accompanies marital breakdown, and that carefully designed legislation would prevent some of the problems reported in other nations. While the Minister for Social Welfare, Proinsias De Rossa, acknowledged shortly before the 1995 referendum that divorce resulted in a loss of income for the family, he noted that such loss was often willingly endured: "It is women, overwhelmingly, who initiate divorce. In every study of divorced women, they say yes, they regret the loss of income, and yes, despite that, they prefer to be divorced rather than endure the continuing

214. DILLON, supra note 32 , at 74 . The ADC accentuated this theme throughout the debate with posters stating, "This amendment will impoverish women: Vote NO!" Id. (quoting the Anti-Divorce Campaign). In short, the ADC argued that divorce was not a workable option for addressing marital breakdown because it would force women and children into poverty. The ADC supported this claim by pointing to statistics from other countries; for example: "in Britain $60 \%$ of women who get a divorce go straight on to social welfare .... [Eighty-eight percent] of low income parents are women. [Sixty-three percent] of that $88 \%$ of low income parents are divorced women." Id. at 75 (quoting Bernadette Bonar, "Today Tonight," Apr. 24, 1986).

215. Id. at 75.

216. Id. (emphasis added) (quoting Bernadette Bonar, "Today Tonight," June 19, 1986).

217. Id. at 76.

218. Id. (quoting William Binchy, "Today Tonight," June 19, 1986). The ADC argued that because sex discrimination is a reality in Irish society, the state's legal protection of marriage as a lifelong commitment represented the best way to compensate women for the discrimination they faced. Id. However, the ADC did not suggest that anything be done to address the problem of sex discrimination itself. 
emotional stress of a bad marriage."219 Accusing Catholic bishops of spreading lies about the effects of divorce on society, De Rossa called on the bishops to consider the actual consequences of divorce in Northern Ireland by examining "two towns in the same diocese, Strabane in Northern Ireland and Lifford in the Republic." 220 De Rossa pointed out that although divorce had been available for more than seventeen years in Strabane and could be obtained there within a six-month period, it had not caused family life and society there to collapse. ${ }^{221}$ He questioned how the introduction of divorce into Lifford, only 100 yards away in the neighboring Republic, where divorce laws would require a four-year separation period, could possibly destroy the community. 222 Furthermore, De Rossa and other divorce supporters rejected their opponents' arguments that approval of the referendum would usher in a new "divorce culture." De Rossa asserted that the government's proposed legislation would in no way allow "Hollywood style divorce" to become the practice in Ireland. ${ }^{223}$ Similarly, Mary O'Rourke, the deputy leader of Fianna Fail, expressly rejected the notion that "having a provision to allow people to remarry [would] usher [Ireland] into a glitzy world of glamour and of temporary relationships."224

\section{B. The Need for Balance}

Meanwhile, across the Atlantic and not far from divorce-ridden Hollywood itself, Dr. Julia Wallerstein, founder of the Center for the Family in Transition in San Francisco, had reason to comment on the debates in Ireland. As the author of a number of studies on divorce and the family, Dr. Wallerstein had been "widely cited by opponents of divorce in the [1995] referendum campaign." 225 In an interview published in The Irish Times, Dr. Wallerstein stated that she fundamentally disagreed with how the anti-divorce campaigners had used her research. ${ }^{226}$ While she agreed that her studies and those of other researchers have shown that divorce is a "serious issue for the family," she emphasized that no study ever has suggested that divorce itself should be abolished. ${ }^{227}$ According to Dr. Wallerstein, no one in the United

219. Carol Coulter, De Rossa Says Bishops Are Telling Lies About Divorce, THE IRISH TIMES, Nov. 21, 1995, at 6 (quoting Proinsias De Rossa).

220. Id.

221. Id.

222. Id.

223. Id. (quoting Proinsias De Rossa).

224. Kelly \& O'Regan, supra note 79 (quoting Mary O'Rourke).

225. Carol Coulter, Allowing Divorce Is Necessary for a "Just Society," THE IRISH TIMES, Nov. 2, 1995, at 7.

226. Id.

227. Id. (quoting Dr. Julia Wallerstein). 
States has argued "from the standpoint that there should be no divorce," 228 as had been the argument in Ireland. Furthermore, she even suggested that divorce is necessary for a just society: "Divorce says you don't have to stay with the mistakes of your youth all your life, nor live alone and in misery. That is the way of a compassionate and just society."229 As Ireland's President Mary Robinson would later do, ${ }^{230} \mathrm{Dr}$. Wallerstein urged Ireland to look to the United States as a model. Unlike President Robinson, however, Dr. Wallerstein pointed to the United States as a model for Ireland of what not to do as the country formulates its divorce laws: "People are quoting me on the mistakes we [the United States] made. You can learn a great deal from our mistakes. We have a lot to teach. . . . It would be foolish not to use our experience. But no one is saying to go back to having no divorce."231

Thus, while Ireland is justified in trying to avoid the problems experienced in liberal divorce jurisdictions like the United States, it should remember that divorce does provide a valuable remedy to the problem of marital breakdown. As Irish lawmakers fashion a new area of law for their country, they will have to balance the interests of the nation's more than 75,000 separated couples, who need a way of ending their broken marriages, against the interests of dependent spouses, ${ }^{232}$ who will need protection against financial hardships in the event of divorce.

\section{Finding a Middle Ground}

The need to enact a divorce law which will enable the efficient dissolution of broken marriages and, at the same time, safeguard against economic hardship, presents a daunting challenge to the Republic of Ireland. Nevertheless, by looking to the laws of the United States, Ireland may be able to glean possible solutions to this challenge.

228. Id. (quoting Dr. Julia Wallerstein).

229. Id. (quoting Dr. Julia Wallerstein).

230. In a speech addressed to the Stanford University Law School on October 18, 1995, President Robinson recognized that the United States would serve as a valuable role model for Ireland as the latter attempts to establish its place within the European Union and the modern world in general. See supra notes 121-22 and accompanying text.

231. Coulter, supra note 225 (quoting Dr. Julia Wallerstein). When asked whether she thought the availability of divorce had adverse consequences for the institution of marriage, Dr. Wallerstein replied, "The laws to change marriage reflect society, not the other way around." Id.

232. The needs of dependent spouses for financial protection compete with, but are not necessarily distinct from, the needs of separated couples for marital dissolution. For example, a wife who is separated from her husband, but who still depends on him for support, may have an interest in both ending her marriage and safeguarding her financial position. 


\section{Step One: Enabling the Dissolution of Broken Marriages}

The constitutional ban on divorce has not prevented marital breakdown from occurring in Ireland. ${ }^{233}$ Despite its Catholic tradition ${ }^{234}$ and its avowed reverence for the family, ${ }^{235}$ Ireland has a real need for divorce due to a large number of broken marriages, ${ }^{236}$ an increasing demand for judicial separations, ${ }^{237}$ and a growing problem of illegitimacy. ${ }^{238}$ Because divorce is generally easier to obtain when there is no requirement that one spouse prove marital misconduct on the part of the other, Ireland should adopt a no-fault ground for divorce. Such a ground could require either the physical separation of the spouses for a prescribed time period or a finding that the marriage has broken down irretrievably. ${ }^{239}$ Indeed, based on the proposed legislation and recent debates on the issue, Ireland does seem prepared to incorporate no-fault principles in establishing the grounds for divorce. For example, as it now stands, the Fifteenth Amendment will allow divorce after a separation period of four years and upon a determination that there "is no reasonable prospect of reconciliation between the spouses." 240 (Note, however, that the proposed requirements mandate that there be both a separation period of four years and a showing that reconciliation is not likely.)

Although the form of divorce proposed in Ireland is non-fault based, the proposed legislation is relatively restrictive in other respects. ${ }^{241}$ First, the

233. See supra note 88.

234. See supra note 75.

235. See supra note 79.

236. See supra text accompanying note 83.

237. See supra note 88.

238. See supra text accompanying notes 86-87.

239. See supra notes $140-45$ and accompanying text.

240. Fifteenth Amendment of the Constitution Act (1995) (Ir.), cited in McDonough, supra note 7, at $656 \mathrm{n} .60$. For full text of the Amendment, see supra note 10.

241. Before the 1995 referendum, the Divorce Action Group ("DAG") was concerned that future divorce legislation would impose strict requirements that would effectively restrict access to divorce. The DAG expressed its concern in a submission to the Government:

To impose either fault-based legislation or over-long waiting periods is to intrude into the private lives of separated persons. While there are emotional aspects to marital breakdown, the Government must not lose sight of the fact that it is the dissolution of the civil contract that is of importance to them as legislators.

Divorce is a civil right. Any attempt to impose a strict regime is a clear signal to [] separated people that they are being judged as irresponsible, immature or at fault. Punishment has no place in civil legislation relating to marital breakdown.

Mary Cummins, DAG Seeks Simple Divorce Referendum, THE IRISH TIMES, June 28, 1993, at 4 (quoting the Divorce Action Group). In light of the Fifteenth Amendment's requirement 
requirement that "at the date of the institution of the proceedings" 242 spouses have lived apart "at least four years during the previous five" ${ }^{243}$ will restrict the number of couples who will have standing even to initiate divorce proceedings. Spouses who already have lived apart for a year ${ }^{244}$ will have to wait three more years just to file for divorce. Furthermore, the requirement seems to discriminate "against those living under the same roof and in conflictual relationships, as well as those who cannot afford to move apart."245 While Mervyn Taylor, the Minister for Equality and Law Reform, has indicated that courts could construe "living apart" to include situations in which both spouses were living under "one roof but . . . in different households, ${ }^{246}$ there is always danger in giving such broad discretion to the judiciary, as demonstrated by the unjust outcomes that occurred under the Judicial Separation Act of 1989. ${ }^{247}$ Second, the Amendment's requirement that there be "no reasonable prospect of reconciliation" requires broad judicial discretion as well. Because "[n]o guidelines identify the evidence that will establish that reconciliation is unlikely," the requirement "lends itself to extensive legal battles with . . . results dependent upon the subjective opinion of the judiciary. ${ }^{248}$

In Professor Anna McDonough's view, Irish lawmakers could avoid the "unfair and inflexible approach to divorce" embodied in the proposed Fifteenth Amendment ${ }^{249}$ by simply declining to write any divorce requirements into the constitution. ${ }^{250}$ According to McDonough, "[t]he rigid approach of placing the standards for divorce into the constitution . . . means

of a four-year separation period, it seems that the DAG's fears of restrictive legislation may become a reality if the proposed Amendment becomes law.

242. Fifteenth Amendment of the Constitution Act, supra note 240 (emphasis added).

243. Id.

244. In the United States, most states require a separation period of one year or less "in the case of a contested, unilateral no-fault divorce." DILLON, supra note 32, at 1 (emphasis added). In comparison, Ireland's requirement of a four-year separation for even an uncontested no-fault divorce seems especially strict.

245. McDonough, supra note 7 , at 660 . The four-year requirement will also cause hardship for those in abusive or dangerous relationships. "Indeed, the physical or emotional force of some spouses may make living apart impossible for those in such relationships." Id. at 661 .

246. Kennedy, supra note 8 (quoting Mervyn Taylor).

247. McDonough, supra note 7, at 661 . See supra text accompanying notes $67-73$ for a discussion of judicial discretion and the unjust results of such discretion under the Judicial Separation Act of 1989.

248. Id.

249. Before the referendum, Progressive Democrat leader Mary Harney claimed that the proposed amendment "offered voters a false choice between two wrongs: one, vote against the [r]eferendum and leave the constitutional ban on divorce in tact, or two, vote for the [r]eferendum, and an unfair and inflexible approach to divorce becomes part of the constitution." Id. at 660 .

250. Id. 
Ireland may only change the requirements by yet another referendum."251 A "more flexible approach" would be to delete the current ban on divorce 252 and "enumerate the requirements [for divorce] in subsequent legislation."253 Because it would allow the legislature to periodically revise the divorce requirements, an approach like McDonough's may offer a viable course of action for Ireland to take in formulating a completely new area of law. Not only would such an approach allow for the easy elimination of inflexible standards such as the four-year separation requirement, it also would prevent abuse of judicial discretion by allowing the legislature to add further guidelines for judges to consider in making such determinations as when reconciliation is unlikely. Thus, even if Irish lawmakers determine that a four-year separation requirement is in the nation's best interest at this point in time, they at least could keep open the possibility of changing such a requirement in the future by not writing it into the constitution now. If lawmakers truly want to make divorce a viable option for ending a broken marriage in Ireland, they must either change the restrictive provisions of the proposed Fifteenth Amendment now or preserve the opportunity for changing equivalent legislation in the future.

\section{Step Two: Preventing Economic Hardship}

Given the demographics of Irish society, it is not surprising that divorce supporters and opponents alike have expressed concern about the effects of divorce on women. The post-divorce economic hardships experienced by many women in the United States would seem even more likely to occur in Ireland, "where the disempowerment of women and their economic dependence is far greater than in the United States." 254 In Ireland, where "the vast majority of married women are dependent economically on their husbands," only twenty-one percent of such women "are engaged in the labor force, compared to [fifty-six] percent of married women in the United States."25s The economic dependence of Irish women stems from the fact that within Irish society a "woman's status [is] dependent on her role as wife

251. Id.

252. Prior to the referendum, the Divorce Action Group took the position that the referendum "should pose only a simple question to voters asking if they are in favour or not of having the ban [on divorce] removed from the Constitution." Cummins, supra note 241. Mags O'Brien, chairperson of DAG, stressed that a simple deletion of the ban from the constitution was the only acceptable approach. According to $O^{\prime} B$ rien, it would be "nonsense" for lawmakers to write "complex family legislation" into the constitution. Id.

253. McDonough, supra note 7 , at 660 .

254. DilloN, supra note 32 , at 80 .

255. Id. "[T]he life chances of the majority of Irish women revolve around marriage and domesticity, an arrangement that is the expressed preference of a majority of Irish married men." Id. 
and homemaker and [is] not related to engagement in the public sphere."256 Indeed, until it was repealed in the mid 1970's, a legislative ban prohibited women from working outside the home after marriage. ${ }^{257}$ Thus, because they depend on marriage for financial security, Irish women would be especially vulnerable to economic hardship at the time of divorce. In order to protect the economic interests of women upon divorce, Irish lawmakers must give careful thought to the standards they design to regulate property distribution and spousal support payments. One way for Ireland to safeguard such interests may be to allow courts to consider fault in making decisions regarding property allocation or maintenance awards, while still preserving a no-fault ground for divorce.

First, it should be noted that although fault-based theory "has been under attack for many years" in the United States, it remains important there "in many contexts and in complex ways." 258 While fault-based theory is typically dismissed as being contrary to the modern trend, half of all states now make use of fault-based doctrines in one way or another. ${ }^{259}$ Significantly, many fault-based laws regarding property distribution and maintenance represent recent reforms of earlier statutes enacted during the no-fault revolution. ${ }^{260}$ Thus, in many states, "even when the divorce is obtained on no-fault grounds, fault may be a factor in awarding post divorce support or in allocating property. " ${ }^{261}$ Such states, which recognize fault in certain contexts, have been deemed "fault-regarding" jurisdictions and occupy a "middle ground" between "fault-blind" jurisdictions, which consider merit and blame within marriage to be irrelevant to divorce, and "fault-driven" jurisdictions, which consider conduct such as adultery and abandonment to be "not only relevant but dispositive of spousal rights and

256. Id. at 78. The Irish Constitution itself relegates women to the domestic sphere:

In particular, the State recognises that by her life within the home, woman gives to the State a support without which the common good cannot be achieved.

The State shall, therefore, endeavor to ensure that mothers shall not be obliged by economic necessity to engage in labour to the neglect of their duties in the home.

IR. CONST. art. 41.2.1-2.

257. DiLlon, supra note 32, at 23-24. Because of this ban, in 1961 only "[five] percent of married women participated in the labor force." Id. at 24.

258. Barbara B. Woodhouse \& Katharine T. Bartlett, Sex, Lies, and Dissipation: The Discourse of Fault in a No-Fault Era, 82 GEO. L.J. 2525, 2531 (1994).

259. Id.

260. Id.

261. Id. at 2532 . 
obligations." 262 While fault-regarding states still "weigh issues of merit and blame," they focus on such issues within "the wider context of the couple's particular marriage, general situation, and shared social norms."263

With respect to property distribution, "the states are almost evenly divided between the fault-blind and limited fault-regarding approaches," with a substantial minority using a fault-driven approach. ${ }^{264}$ Those states applying the "limited" fault-regarding approach give weight to a form of misconduct different from the traditional forms of marital misconduct such as adultery or cruelty. The misconduct with which such states are concerned has been termed "economic fault" and occurs whenever there is misuse, waste, or dissipation of assets during a marriage. ${ }^{265}$ With respect to maintenance, fault traditionally has played a significant role in the determination of awards. ${ }^{266}$ Fault may determine one spouse's eligibility to receive maintenance, the other's obligation to pay it, and the amount of the award. ${ }^{267}$ In each of these determinations, as in determinations involving property distribution, "fault can either play a dispositive role, figure as one of many factors, or be excluded as irrelevant."268 Furthermore, as in the property allocation context, economic fault often factors into a court's decision on how much support to award. ${ }^{269}$

Because its proposed divorce legislation is already relatively restrictive, Ireland should not make fault a requirement for obtaining divorce. Nevertheless, by allowing judges to consider fault, whether in the form of marital or economic misconduct, when dividing marital property or awarding

262. Id. at 2532-33.

263. Id. at 2533.

264. Id. at 2535.

265. Id. at 2533-34. UMDA § 307, which specifies certain factors for judges to consider in deciding how to divide marital property, directs courts to look at "the contribution or dissipation of each party in the acquisition, preservation, depreciation, or appreciation in value of the respective estates, and the contribution of a spouse as a homemaker or to the family unit." Starnes, supra note 20, at $92 \mathrm{n} .111$ (emphasis added) (quoting UMDA § 307, 9A ULA 238 (West 1987) (Alternative A)). Thus, in jurisdictions adopting similar statutes, economic fault on the part of either spouse may affect how a judge decides to divide the marital property.

266. Woodhouse \& Bartlett, supra note 258 , at 2536 . The concept of maintenance itself originates from fault-based theory. Under the common law, alimony "originated as the continuing right of an innocent wife-one who had been abandoned or had justifiably left her husband-to support [from her husband]." Id. at 2535. Thus, alimony "was predicated not on a division of income-providing assets already accumulated, but instead on punishing misconduct." Id. at 2536.

267. Id. at 2536.

268. Id.

269. Id. at 2538. Jurisdictions that consider economic fault in determining support payments often look for evidence of the "depreciation or dissipation of marital property" by one of the spouses. Id. 
maintenance, Ireland may be able to alleviate some of the economic hardships that would otherwise be experienced by women upon divorce. For example, in a case where the husband abandons the wife during the course of the marriage, the judge could acknowledge the husband's misconduct and either award the wife a greater portion of the marital property or order the husband to pay support to her. Because courts will lack the guidance of legal precedence when divorce first becomes available in Ireland, they should apply a fault-regarding approach in their decisions, since such a method will enable them to consider fault in the "wider context of the couple's particular marriage." 270 The flexibility of a fault-regarding approach also will allow judges to take into account the disadvantaged position that women occupy within Irish society. Thus, in a case where the wife commits adultery during the course of the marriage, the judge would still have the latitude to give her an equal share of the property or a fair maintenance award, if her economic situation so necessitated. By giving courts discretion where discretion is needed (i.e., in determining the economic entitlements and obligations of the parties), and by denying courts discretion where such discretion could produce uncertain or unjust results (i.e., in determining whether the grounds for divorce have been met), legislation with a no-fault ground for divorce and a fault-based distributive scheme would enable Ireland both to provide divorce as a remedy for marital breakdown and to safeguard the economic interests of women upon divorce.

\section{CONCLUSION}

No matter what course of action Irish lawmakers take in formulating a new area of law for their country, the legalization of divorce is bound to have a profound impact on Irish society. Even with the granting of the first divorces, dramatic changes will occur in the structure of Irish society. Children who are the product of second relationships will no longer be shunned as "illegitimate." 271 On the other hand, children of a marriage which ends in divorce may have to adjust to a living arrangement in which their parents share custody of them. ${ }^{27}$ Couples who have suffered for years in broken marriages will be free to end their troubled relationships and begin their lives anew. However, for some financially dependent spouses, the price of a fresh start may be a decreased standard of living or other economic hardship. Just as divorce has altered the fabric of American society during the latter part of the twentieth century, the introduction of 
divorce may have serious ramifications on Irish society within the near future.

Whatever problems may result from divorce in the future, "a divided Irish society poses a problem for the nation today."273 The impassioned campaigns preceding the 1995 referendum, along with the narrow majority by which the referendum passed, highlighted a deep division within Irish society. While the Catholic Church has molded the nation of Ireland, ${ }^{274}$ and many of Ireland's laws have been based on traditional Christian morality, the nation is now divided between those who wish to preserve Catholic traditions and those who view the secularization of Ireland as an opportunity for the nation to join the modern world. ${ }^{275}$ With just $50.3 \%$ of the electorate voting to allow divorce, it is clear that the 1995 referendum did not mend the division in Irish society; indeed, the narrow passage of the referendum, after months of emotional campaigning by both sides, may have intensified the schism. ${ }^{276}$ While "traditionalists grapple for the past and modernists fight for future change," what will happen to Irish society remains uncertain. ${ }^{277}$

While it would be dangerous for legislators, in planning for Ireland's future, to ignore the major social schism dividing the nation, ${ }^{278}$ the fact remains that "the divorce referendum marked a crucial stage in [Ireland's] political development. ${ }^{279}$ The 1995 referendum presented voters "with a

273. Id.

274. See supra note 75 and accompanying text.

275. McDonough, supra note 7, at 672. Although the Catholic Church has long existed as a moral stronghold in the Republic of Ireland, a recent poll conducted by The Irish Times suggests that the Church's moral authority is declining. Andy Pollak, Poll Shows Church's Moral Authority in Decline, THE IRISH TIMES, Dec. 16, 1996, at 5. The poll reported that only $21 \%$ of Catholics surveyed said that they followed the teachings of the Church when making "serious moral decisions," compared to $78 \%$ who said they followed their own conscience. Id. (quoting the poll's language). Such figures suggest that "Ireland is moving towards the European cultural mainstream in its religious attitudes." Id. The poll further found that only $27 \%$ of those questioned believed that "the great majority of people in Ireland will still practice Catholicism in 20 years time." Id. Sixty-nine percent believed that "in 20 years time Ireland will be Catholic in name, but only a minority will be practising their Catholicism." Id. As additional evidence of the declining influence of the Church, Mass attendance has been falling. When asked how often they attended Mass ten years ago, $85 \%$ of those polled said once a week. When asked how frequently they went five years ago, $79 \%$ said once a week. "Now only 66 per cent [sic] of those polled say they attend Mass at least once a week." Id.

276. McDonough, supra note 7, at 672.

277. Id.

278. In planning for the future, Irish lawmakers "must realize that the nation is sharply divided" over certain matters of social policy. Id. The fact that $49.7 \%$ of the population did not support the introduction of divorce suggests that " $[\mathrm{t}]$ he nation will divide even more should the government make rash movements toward modernization." Id.

279. Mary Holland, Lectures on "Welfare Fraud" Ring Very Hollow, THE IRISH TIMES, Dec. 5, 1996, at 16. 
clear but difficult choice between sincerely held, traditional beliefs that were very precious to many people, and an alternative which would have a dramatic impact on Irish society, not necessarily for the better." ${ }^{280}$ In light of the difficult choice that voters faced, it took a significant amount of courage for them to "face up to the fact that Ireland had to deal with the problem of marital breakdown in an honest and clearsighted way and to vote accordingly." 281 If nothing else, the divorce referendum may have "put an end . . . to the notion of an Irish solution to an Irish problem."282 Indeed, in recent years, Ireland seems to have recognized that its sociopolitical problems are not unique, and that it can no longer isolate itself from the rest of the world. ${ }^{283}$ Even if Ireland has entered the modern world with half of its population dragging its feet, it nevertheless has arrived in a new place. As Irish lawmakers navigate this new territory on behalf of their nation, they would be well-advised to study the paths taken by previous explorers. Having entered the realms of both fault-based and no-fault divorce, the United States is one explorer whose successes and failures may serve as lessons in law to Ireland.

Sarah E. Fette

280. Id.

281. Id.

282. Id.

283. See supra notes 110-11 and accompanying text.

* J.D. candidate, 1998, Indiana University School of Law-Indianapolis; A.B., 1995 , University of Michigan. 
